\title{
Ecological Potential of Plants for Phytoremediation and Ecorestoration of Fly Ash Deposits and Mine Wastes
}

\author{
Gordana Gajić*, Lola Djurdjević, Olga Kostić, SneŽana Jarić, Miroslava Mitrović and \\ Pavle Pavlović
}

Department of Ecology, Institute for Biological Research "Siniša Stanković", University of Belgrade, Belgrade, Serbia

\section{OPEN ACCESS}

Edited by:

Mira Aničić Urošević,

University of Belgrade, Serbia

Reviewed by:

Vimal Chandra Pandey,

Babasaheb Bhimrao Ambedkar

University, India

Jelena Avdalovic,

Institute of Chemistry, Technology and Metallurgy, University of Belgrade,

Serbia

*Correspondence: Gordana Gajić gugol@ibiss.bg.ac.rs; gocagajic@gmail.com

Specialty section:

This article was submitted to

Environmental Toxicology,

a section of the journal

Frontiers in Environmental Science

Received: 04 June 2018

Accepted: 04 October 2018

Published: 13 November 2018

Citation:

Gajić G, Djurdjević L, Kostić O, Jarić S, Mitrović $M$ and Pavlović $P$ (2018) Ecological Potential of Plants

for Phytoremediation and

Ecorestoration of Fly Ash Deposits and Mine Wastes.

Front. Environ. Sci. 6:124. doi: 10.3389/fenvs.2018.00124
Fly ash generates as the result of coal combustion in thermoelectric power stations whereas ore mining activities produce mine waste-rock and tailings worldwide. High concentrations of metal(loid)s and organic pollutants in fly ash and mine wastes are released into soil, air, and water presenting a global threat to the surrounding environment and human health. The environmentally sound management of fly ash and mine wasterock and tailings includes monitoring stability of the dam construction and seepage flowrate, prevention of water erosion and dust spreading, reducing the footprint of the management facilities and successful restoration/revegetation. Harsh conditions prevailing on fly ash and mine deposits are unfavorable mechanical composition and $\mathrm{pH}$, high concentrations of soluble salts, lack of nitrogen and phosphorous, reduced number of microorganisms and fungus, toxic concentrations of $\mathrm{As}, \mathrm{Au}, \mathrm{Ag}, \mathrm{B}, \mathrm{Cu}, \mathrm{Cd}$, $\mathrm{Cr}, \mathrm{Hg}, \mathrm{Mn}, \mathrm{Mo}, \mathrm{Ni}, \mathrm{Pb}, \mathrm{Zn}$, and the presence of PAHs and PCBs. The review addresses phystostabilization, phytoextraction, rhizodegradation, and phytodegradation as main phytoremediation green technologies which use plants to clean up the contaminated area to safe levels. Establishment of the self-sustaining vegetative cover on fly ash and mine deposits is crucial for recovering ecosystem health, stability, and resilience. Therefore, here we have discussed the essential role of native plants in the ecorestoration process on waste deposits. Additional emphasis is given to the evaluation of plant adaptive response to pollution stress. This review presents a current knowledge in phytomanagement of fly ash deposits, mine waste-rock and tailings. Also, it provides a new frontier in restoration physiology where physiological and biochemical tools can be used to predict plant response to stressors and success of restoration projects.

Keywords: fly ash, mine waste, pollutants, phytoremediation, ecorestoration, native plants, plant physiology, adaptation

\section{INTRODUCTION}

Thermal power plants using coal as major fuel for production of electricity worldwide generate large amounts of combustion coal residues (CCRs), such as fly ash, bottom ash, boiler slag and flues gas desulphurization materials (Heidrich et al., 2013). According to Yao et al. (2015) coal consumption in thermal power stations in world electricity supply should increase from $29.9 \%$ in 2011 to $46 \%$ in 2030. The coal reserves in the world are over $850 \mathrm{Gt}$ with large producing countries: North America (240 Mt), Russian Federation (170 Mt), China (130 Mt), Europe and Eurasia 
(130 Mt), Australia (80 Mt), India (70 Mt), Middle East and Africa (40 Mt), Central and South America (30 Mt) and other Asian Pacific countries (10 Mt) (World Coal Association, 2012; Heidrich et al., 2013). The annual production of fly ash reaches approximately 580 million tons in China, 160 million tons in India and 130 million tons in US (Yao et al., 2015). Improper disposal of coal fly ash presents environmental and human health hazards. However, efforts have been made to develop different recycling technologies addressing fly ash utilization. Thus, fly ash can be used as building material, backfills for road constructions and pavement base, for cement and brick manufacturing, filler in asphalt mixture, soil stabilization as cover suitable for soil reclamation, material recovery, manufacturing mineral wool, and zeolite synthesis (Heidrich, 2005). Effective utilization of CCRs is $53 \%$ of total production (Heidrich et al., 2013).

The opencast coal and metal mining result in the formation of substantial amounts of different types of mine waste materials which depend on the geology at the mine area, physicochemical composition, process technology, and mining operation (extraction, beneficiation, processing minerals) as well as how they are managed at the site (Maiti, 2013). Some mine wastes include: (a) overburden that presents natural soil or massive rock which is removed to gain access to the ore deposits at open pit mines and it is settled on the surface at the mine site; (b) waste rock which contains industrial minerals which cannot be extracted as market products and they are usually stored in heaps and dumps on the mine site; (c) tailings: coarse (dry) fractions of mineral waste products which remain after processing material extraction for profit; fine (wet) fractions resulting from flotation as mineral separation technique used for getting valuable products from the coarse fraction. Coarse and fine fractions of mineral waste are settled into tailings pond and heap and enclosed by dams (Europian Commision, 2009). However, sometimes, waste materials are turned into resources: overburden may be used for revegetation during mine closure, waste rock can be reprocessed to extract minerals and metals and used as backfill, aggregate in road construction and concrete whereas manganese and clay-rich tailings have been used in agro-forestry and construction materials (bricks and cement) (Lottermoster, 2012).

Coal fly ash is usually disposed by the "wet" method on the artificially made lagoons where fly ash and slag are mixed with water (Reijnders, 2005). From this suspension overflow and drainage wastewaters are generated and discharged indirectly through the drainage channels into the river. The drainage well-system is often located along the periphery of the embankment to prevent disturbance of the surrounding terrain and chemical pollution of groundwater. The raising of the peripheral embankments is achieved by hydrocycling of the ash, whereby the ash fractions are separated from the pulp and directed into a special device for "building" the dam. On the landfill, measures of protection are implemented in order to reduce the negative impact of fly ash on the environment. That is achieved by maintaining the drainage channels around the landfill, drainage wells throughout the entire landfill, maintaining the maximum surface of the water mirror (lakes) on the active cassette $(25-55 \%$ of the surface), using a cannon system for watering dry surfaces inside the flat part of the landfill, using a spray system for watering embankments and grass cover and conducting biological recultivation i.e., sowing grass and planting woody and bushy plant species Gajić et al., 2016. The fly ash disposal is done usually in cassettes where one is active and others are passive, and can be used for the technical consolidation of fly ash and drainage, but also in the case of accidents or the cessation of fly ash.

The facilities of mine tailings and waste rock can be swimming-pool tailings ponds and small or large ponds over 100 or 1,000 hectares. Waste rock and tailings heap can be over $200 \mathrm{~m}$ high. Managing mine waste includes: discarding slurried tailings into ponds, surface water and groundwater; disposal of dry tailings or waste rock onto heaps or backfilling into underground mines or open pits; using them for the construction of tailings dam or land restoration. The choice of applied methods depends on cost, environmental impacts, and risk of failure (Europian Commision, 2009). 'Best available techniques' (BAT) for the environmentally sound management of tailings and waste rock include management strategies, monitoring, and risk assessment such as life-cycle management (design, construction, operational phases, closure, and after-care phase), prevention and control of water erosion and dust spreading, acid rock drainage (ARD) management (active/passive treatment, addition of buffering minerals), drainage of ponds, seepage management, accident prevention (dam design and construction, raising and operation of pond, and monitoring stability of tailings pond), restoration/revegetation heaps or dams, reduction of footprint (backfilling of waste materials), mitigation of accidents, closure, and after-care of facilities (Europian Commision, 2009). Therefore, BAT applies risk/safety and environmental management system (EMS).

Mining activities and coal production from surface mines as well as ore and fly ash disposal produce large changes in landscape, lead to land degradation, deterioration of air and water quality, near-total loss of vegetation, affecting negatively fauna, and human beings (Maiti, 2013; Gajić and Pavlović, 2018). Fly ash and mine waste-rock and tailings contain many metal(loid)s and persistent organic pollutants (POP)s which can be released in the environment leading to water, air and soil pollution (Jala and Goyal, 2006). Furthermore, fine particles can be dispersed due to wind in the surrounding environment affecting human health i.e., they provoke irritation in eyes, skin, noise, throat and respiratory system leading to anemia, asthma, bronchitis and cancer diseases (US Environmental Protection Agency, 2007).

This review is focused on unfavorable conditions prevailing on fly ash and mine waste deposits, and ecorestoration and phytoremediation of these anthropogenic sites worldwide. We discuss plant response to metal(loid)s stress i.e., uptake and translocation of metal(loid)s through transporter mechanisms and plant tolerance strategies (exclusion and accumulation) with special emphasis on chelation and antioxidant machinery. Sound knowledge is essential for the selection of native plant species that establish a self-sustaining vegetation cover providing sustainable green cleanup and successful ecorestoration of contaminated sites. 


\section{LIMITING FACTORS FOR PLANT GROWTH ON FLY ASH AND MINE WASTE DEPOSITS}

Limiting factors for plant growth on fly ash deposits and mine spoil are unforable mechanical composition and $\mathrm{pH}$, high concentrations of soluble salts, lack of essential nutrients, such as $\mathrm{N}$ and $\mathrm{P}$, toxic concentrations of $\mathrm{As}, \mathrm{B}, \mathrm{Cd}, \mathrm{Cr}, \mathrm{Cu}, \mathrm{Hg}, \mathrm{Mn}$, $\mathrm{Mo}, \mathrm{Ni}, \mathrm{Pb}$, Se, reduced number of microorganisms that can fix nitrogen and reduced presence of mycorrhizae (Adriano et al., 1980; Pavlović et al., 2004; Mitrović et al., 2008; Haynes, 2009; Pandey, 2013; Pandey and Singh, 2014; Gajić et al., 2016; Gajić and Pavlović, 2018). Natural soil is different from fly ash and mine spoil mostly due to no or poorly developed soil structure throughout the profile, coarse texture with more sand fractions and less clay content whereas the content of N, P and other essential nutrients is very low (Maiti, 2013).

Generally, unweathering fly ash showed sandy structure (56.0-82.0\%, Weber et al., 2015; 97.1\%, Gajić et al., 2016; Kostić et al., 2018) with small amounts of colloidal particles (1.8\%, Gajić et al., 2016; Kostić et al., 2018) and low percentage of hydroscopic water $(0.54 \%$, Gajić et al., 2016) that results in great water permeability and weak aggregation indicating adverse physical conditions for plant growth (Weber et al., 2015; Kostić et al., 2018) (Table 1). Furthermore, high values of electrical conductivity (EC) $(150 \mu \mathrm{S} / \mathrm{cm}$, Pandey and Singh, 2014; 0.352 dS/m, Gajić et al., 2016; Kostić et al., 2018) (Table 1) indicate a large amount of soluble salts whereas $\mathrm{pH}$ values can vary from 4.5 to 12 depending on coal type (Carlson and Adriano, 1993; Bilski et al., 1995). Thus, lignite and bituminous coal have alkaline fly ash, more $\mathrm{Ca}$ and less S (8.10, Pandey et al., 2012; 8.5-9.9, Weber et al., 2015; 7.9, Gajić et al., 2016) (Table 1). In addition, $\mathrm{pH}$ values from 7 to 10 enhance the release of As, $\mathrm{Cr}, \mathrm{Mo}, \mathrm{Se}, \mathrm{Sb}$, $\mathrm{V}$, and $\mathrm{W}$ whereas $\mathrm{Cd}, \mathrm{Cr}, \mathrm{Cu}, \mathrm{Fe}, \mathrm{Mn}, \mathrm{Ni}, \mathrm{Pb}, \mathrm{Si}$, and $\mathrm{Zn}$ have maximum leachability pH under 7 (Izquierdo and Querol, 2012). The carbon content in unweathering fly ash is high (Gajić et al., 2016; Kostić et al., 2018) probably due to incomplete combustion of coal and may partly compensate the lack of organic matter (Fettweis et al., 2005). The nitrogen content $(0.02 \%$, Gajić et al., 2016; Kostić et al., 2018; 0.049\%, Jambhulkar and Juwarkar, 2009) and available $\mathrm{K}_{2} \mathrm{O}$ and $\mathrm{P}_{2} \mathrm{O}_{5}$ content $(0.19,0.17 \%$, Jambhulkar and Juwarkar, 2009; 75.4, 21.1\%, Pandey and Singh, 2014; 15.0 $\mathrm{mg} / 100 \mathrm{~g}, 7.49 \mathrm{mg} / 100 \mathrm{~g}$, Kostić et al., 2018) in fly ash are low (Pandey and Singh, 2014) (Table 1). However, total metal(loid)s concentration in fly ash, such as As, B, Cd, Cr, Co, Cu, Mn, $\mathrm{Mo}, \mathrm{Ni}, \mathrm{Pb}$, Se can be toxic and can vary depending on coal, combustion conditions, operating parameters, transport system, leaching processes, effects on plants, and climatic conditions (Adriano et al., 1980; Haynes, 2009). Over time, proportion of total sand in fly ash is reduced (83.3-71.6\%, Gajić et al., 2016) and the clay fraction is increased (1.2-2.5\%, Gajić et al., 2016) whereas the percentage of hygroscopic water is increased (0.56$2.3 \%$, Gajić et al., 2016) and this all together provides good aggregation and capillarity (DŽeletović and Filipović, 1995; Gajić et al., 2016). In weathering fly ash, EC values $(101.4 \mu \mathrm{S} / \mathrm{cm}$, Pandey and Singh, 2014; 0.217-0.190 dS/m, Gajić et al., 2016) and $\mathrm{pH}$ decreased (7.95-7.87, Gajić et al., 2016; 8.85, Pandey and Singh, 2014), content of organic carbon (1.85-1.13\%, Gajić et al.,
2016; 2.05\%, Jambhulkar and Juwarkar, 2009) and total nitrogen (0.06-0.11\%\%, Gajić et al., 2016; 0.05\% Pandey and Singh, 2014) as well as the available content of $\mathrm{K}_{2} \mathrm{O}$ and $\mathrm{P}_{2} \mathrm{O}_{5}$ increased (52.5 mg/100 g and $10.1 \mathrm{mg} / 100 \mathrm{~g}$, Gajić et al., 2016; 38.2-59.5 $\mathrm{mg} / 100 \mathrm{~g}, 25.3 \mathrm{mg} / 100 \mathrm{~g}$, Kostić et al., 2018). The content of some elements (As, B, Cu, Mn, Mo, Zn) in weathering fly ash decreased as a result of leaching and strong element binding by $\mathrm{Al}, \mathrm{Si}$, and Fe oxides, clay and organic matter (Haynes, 2009; Gajić et al., 2016). Taken together, plant species growing on weathering fly ash deposits improve physico-chemical properties of fly ash providing favorable conditions for further plant growth (Weber et al., 2015; Gajić et al., 2016; Gajić and Pavlović, 2018).

Mine wastes show great heterogeneity in their texture and physico-chemical properties in metallic mining area. The wide range of mine spoil characteristics is related to differences in mineralogical substrate and composition of mine residue which can come from different ore minerals and veins as well as from the exploitation procedures, plant cover and climatic conditions (Gomez-Ros et al., 2013; Ruiz Olivares et al., 2013). Thus, on the more or less revegetated mining tailings the fractions of sand, silt and clay vary greatly $(55-73,22-33,5-12 \%$ respectively, Conesa et al., 2006; 97.8, 0.96, 1.27\% respectively, Randjelović et al., 2016) (Table 1). In addition, the mining wastes show different $\mathrm{pH}$ values from acid (2.5, Conesa et al., 2006; 3.14-3.30, Bes et al., 2014; 4.2-4.7, Santos et al., 2016), neutral to slightly alkaline (6.6-7.3\%, Conesa et al., 2006; 6.85\%, Randjelović et al., 2016; 7.1-7.5, Parraga-Aguado et al., 2014) to moderately alkaline values (8.2-8.4, Gomez-Ros et al., 2013; 8.52-8.66, Fernandez et al., 2017) (Table 1). Furthermore, the range of EC is also wide $(6.4-18 \mathrm{dS} / \mathrm{m}$, Conesa et al., 2006; 1.7$3.4 \mathrm{dS} / \mathrm{m}$, Parraga-Aguado et al., 2014; $2.49-15.5 \mathrm{dS} / \mathrm{m}$, Bes et al., 2014) where these values increased from the border of mine tailings to the plateau of barren area (Parraga-Aguado et al., 2013) (Table 1). The values of organic carbon $(0.5 \%$, Conesa et al., 2006; 0.17-0.48\%, Bes et al., 2014; 1,55\% Randjelović et al., 2016; 3.14-6.65\%, Parraga-Aguado et al., 2014; 15.133.3, Santos et al., 2016) and total nitrogen (0.04\%, Bes et al., 2014; $0.29-0.62 \%$, Parraga-Aguado et al., 2014; $0.5-1.2 \%$, Santos et al., 2016) also vary as well as available content of $\mathrm{K}_{2} \mathrm{O}$ (7.67-37.0 mg/100 g, Randjelović et al., 2016; 42.3-129.0 g/kg, Santos et al., 2016) and $\mathrm{P}_{2} \mathrm{O}_{5}(0.05-24.0 \mathrm{mg} / 100 \mathrm{~g}$, Randjelović et al., 2016; 0.9-74.3 mg/kg, Santos et al., 2016) (Table 1). The mine spoils on the tailings showed multielement pollution with high total concentrations of $\mathrm{As}, \mathrm{Cd}, \mathrm{Cu}, \mathrm{Fe}, \mathrm{Hg}, \mathrm{Mn}$, $\mathrm{Ni}, \mathrm{Pb}, \mathrm{Sb}, \mathrm{Zn}$ that exceed local background values and the maximum allowed values proposed by any country legalization as well as agricultural/residential/commercial/industrial use and they largely depend on geochemical partitioning (Gomez-Ros et al., 2013; Parraga-Aguado et al., 2013; Ruiz Olivares et al., 2013; Bes et al., 2014; Randjelović et al., 2016; Santos et al., 2016).

\section{ECORESTORATION OF FLY ASH AND MINE WASTE DEPOSITS}

Development of vegetation cover on fly ash and mine waste deposits is significant because plant species stabilize 
TABLE 1 | Physico-chemical characteristics of fly ash and mine waste.

\begin{tabular}{|c|c|c|c|c|c|c|}
\hline Parameters & $\begin{array}{l}\text { Unweathered } \\
\text { fly ash }\end{array}$ & References & $\begin{array}{l}\text { Weathered fly } \\
\text { ash }\end{array}$ & References & Mine waste & References \\
\hline Sand (\%) & $\begin{array}{l}56.0-82.0 \\
97.1\end{array}$ & $\begin{array}{l}\text { Weber et al., } 2015 \\
\text { Gajić et al., 2016; } \\
\text { Kostić et al., } 2018\end{array}$ & $83.3-71.6$ & Gajić et al., 2016 & $\begin{array}{l}55-73 \\
97.8\end{array}$ & $\begin{array}{l}\text { Conesa et al., } 2006 \\
\text { Randjelović et al., } 2016\end{array}$ \\
\hline Silt (\%) & $\begin{array}{l}17.0-40.0 \\
9.4 \\
1.11\end{array}$ & $\begin{array}{l}\text { Weber et al., } 2015 \\
\text { Gajić et al., } 2016 \\
\text { Kostić et al., } 2018\end{array}$ & $25.7-40.8$ & Gajić et al., 2016 & $\begin{array}{l}22-33 \\
0.96\end{array}$ & $\begin{array}{l}\text { Conesa et al., } 2006 \\
\text { Randjelović et al., } 2016\end{array}$ \\
\hline Clay (\%) & $\begin{array}{l}1.0-4.0 \\
1.8 \\
1.78\end{array}$ & $\begin{array}{l}\text { Weber et al., } 2015 \\
\text { Gajić et al., } 2016 \\
\text { Kostić et al., } 2018\end{array}$ & $1.2-2.5$ & Gajić et al., 2016 & $\begin{array}{l}5-12 \\
1.27\end{array}$ & $\begin{array}{l}\text { Conesa et al., } 2006 \\
\text { Randjelović et al., } 2016\end{array}$ \\
\hline Higroscopic water (\%) & 0.54 & $\begin{array}{l}\text { Gajić et al., } 2016 \\
\text { Kostić et al., } 2018\end{array}$ & $0.56-2.3$ & Gajić et al., 2016 & - & - \\
\hline $\mathrm{pH}$ & $\begin{array}{l}8.10 \\
8.5-9.9 \\
7.9 \\
8.03\end{array}$ & $\begin{array}{l}\text { Pandey et al., } 2012 \\
\text { Weber et al., } 2015 \\
\text { Gajić et al., } 2016 \\
\text { Kostić et al., } 2018\end{array}$ & $\begin{array}{l}7.95-7.87 \\
8.85\end{array}$ & $\begin{array}{l}\text { Gajić et al., } 2016 \\
\text { Pandey and Singh, } 2014\end{array}$ & $\begin{array}{l}2.5-7.3 \\
3.14-3.30 \\
4.2-4.7 \\
6.85 \\
7.1-7.5 \\
8.2-8.4 \\
8.52-8.66\end{array}$ & $\begin{array}{l}\text { Conesa et al., } 2006 \\
\text { Bes et al., } 2014 \\
\text { Santos et al., } 2016 \\
\text { Randjelović et al., } 2016 \\
\text { Parraga-Aguado et al., } 2014 \\
\text { Gomez-Ros et al., } 2013 \\
\text { Fernandez et al., } 2017\end{array}$ \\
\hline $\begin{array}{l}\text { Electrical conductivity } \\
(E C, \mu S / m ; d S / m)\end{array}$ & $\begin{array}{l}150 \\
0.352 \\
0.353\end{array}$ & $\begin{array}{l}\text { Pandey and Singh, } 2014 \\
\text { Gajić et al., } 2016 \\
\text { Kostić et al., } 2018\end{array}$ & $\begin{array}{l}101.4 \\
0.217-0.190\end{array}$ & $\begin{array}{l}\text { Pandey and Singh, } 2014 \\
\text { Gajić et al., } 2016\end{array}$ & $\begin{array}{l}6.4-18 \\
1.7-3.4 \\
2.49-15.5\end{array}$ & $\begin{array}{l}\text { Conesa et al., } 2006 \\
\text { Parraga-Aguado et al., } 2014 \\
\text { Bes et al., } 2014\end{array}$ \\
\hline $\begin{array}{l}\text { Carbon content } \\
(\mathrm{C}, \%)\end{array}$ & 3.19 & $\begin{array}{l}\text { Gajić et al., } 2016 \\
\text { Kostić et al., } 2018\end{array}$ & $\begin{array}{l}1.85-1.13 \\
2.05\end{array}$ & $\begin{array}{l}\text { Gajić et al., } 2016 \\
\text { Jambhulkar and Juwarkar, } \\
2009\end{array}$ & $\begin{array}{l}0.5 \\
0.17-0.48 \\
1.55 \\
3.14-6.65 \\
15.1-33.3\end{array}$ & $\begin{array}{l}\text { Conesa et al., } 2006 \\
\text { Bes et al., } 2014 \\
\text { Randjelović et al., } 2016 \\
\text { Parraga-Aguado et al., } 2014 \\
\text { Santos et al., } 2016\end{array}$ \\
\hline $\begin{array}{l}\text { Nitrogen content } \\
(\mathrm{N}, \%)\end{array}$ & $\begin{array}{l}0.049 \\
0.02\end{array}$ & $\begin{array}{l}\text { Jambhulkar and Juwarkar, } 2009 \\
\text { Gajić et al., } 2016 \\
\text { Kostić et al., } 2018\end{array}$ & $\begin{array}{l}0.06-0.11 \\
0.05\end{array}$ & $\begin{array}{l}\text { Gajić et al., } 2016 \\
\text { Pandey and Singh, } 2014\end{array}$ & $\begin{array}{l}0.04 \\
0.29-0.62 \\
0.5-1.2\end{array}$ & $\begin{array}{l}\text { Bes et al., } 2014 \\
\text { Parraga-Aguado et al., } 2014 \\
\text { Santos et al., } 2016\end{array}$ \\
\hline $\begin{array}{l}\text { Available potassium } \\
\left(\mathrm{K}_{2} \mathrm{O}, \% ; \mathrm{mg} / 100 \mathrm{~g}\right)\end{array}$ & $\begin{array}{l}0.007 \\
36 \\
15.0\end{array}$ & $\begin{array}{l}\text { Jambhulkar and Juwarkar, } 2009 \\
\text { Pandey and Singh, } 2014 \\
\text { Kostić et al., } 2018\end{array}$ & $\begin{array}{l}52.5 \\
38.2-59.5\end{array}$ & $\begin{array}{l}\text { Gajić et al., } 2016 \\
\text { Kostić et al., } 2018\end{array}$ & $\begin{array}{l}42.3-129.0 \\
21.2\end{array}$ & $\begin{array}{l}\text { Santos et al., } 2016 \\
\text { Randjelović et al., } 2016\end{array}$ \\
\hline $\begin{array}{l}\text { Available phosphorous } \\
\left(\mathrm{P}_{2} \mathrm{O}_{5}, \% ; \mathrm{mg} / 100 \mathrm{~g}\right)\end{array}$ & $\begin{array}{l}0.016 \\
7.26 \\
7.49\end{array}$ & $\begin{array}{l}\text { Jambhulkar and Juwarkar, } 2009 \\
\text { Pandey and Singh, } 2014 \\
\text { Kostić et al., } 2018\end{array}$ & $\begin{array}{l}10.1 \\
25.5\end{array}$ & $\begin{array}{l}\text { Gajić et al., } 2016 \\
\text { Kostić et al., } 2018\end{array}$ & $\begin{array}{l}0.9-74.3 \\
7.99\end{array}$ & $\begin{array}{l}\text { Santos et al., } 2016 \\
\text { Randjelović et al., } 2016\end{array}$ \\
\hline
\end{tabular}

fly ash and mine spoil, prevent wind erosion, decrease mobility, toxicity, and dispersion of chemical elements in the surrounding environment, provide the organic substance which can bind contaminants and reduce transfer of pollutants in the food web (DŽeletović and Filipović, 1995; Pavlović et al., 2004; Djurdjević et al., 2006; Mitrović et al., 2008; DŽeletović et al., 2009; Haynes, 2009; Pandey, 2012; Maiti, 2013; Pandey et al., 2015a,b, 2016a; Gajić et al., 2016). Therefore, ecorestoration of degraded sites is the process of renewing ecosystem stability and resilience after stress or disturbance with respect to its health, integrity and sustainability (SER, 2002) presenting a key issue in environmental science and ecological engineering.

Native plant species grow in a particular area over a long period of time without human intervention and possess certain characteristics that make them the best adapted to local conditions providing practical and ecologically valuable alternative for landscaping and ecorestoration projects (Richards et al., 1998; Dorner, 2002). Phytomanagement of degraded sites encourages selection of native species that in the long run form self-sustaining plant communities that do not require much maintenance. Establishing successful vegetation cover from native plant species on disturbed land promotes natural revegetation. Thus, selected native plants should have the following characteristics: (a) easy to establish, (b) fast growth, (c) deep root system, (d) capacity for nitrogen fixation, (e) tolerance to local climate; (f) tolerance to adverse physico-chemical conditions; (g) favorable growth with other species of the mixture; (h) capability to improve substrate fertility through organic matter and nutrient cycling (Maiti, 2013).

Successful ecorestoration is achieved by establishment of the self-sustaining vegetation cover through human intervention by seeding the mixture of grasses and legumes, and planting shrubs and trees (Pavlović et al., 2004; Mitrović et al., 2008; Kostić et al., 2012; Maiti, 2013; Gajić et al., 2016). In a temperate climate, grass and legume species that are the best for the revegetation of degraded sites belong to the genus of 
Festuca, Lolium, Agropyron, Poa, Medicago, and Vicia whereas the trees that provide good phytostabilization of substrates are Poplar, Robinia, Salix, Alnus, Betula, and Acer (Prasad, 2006). However, in tropical region different plant genus are the best choice for the recultivation of degraded sites: Chloris, Pennisetum, Vetiveria, Paspalum, Cynodon (grasses); Leucaena, Acacia, and Sesbania (legumes) and Prosopis, Eucaliptus and Ricinus (trees) (Prasad, 2006). Legumes present keystone species because they provide nitrogen as the critical, most important resource on fly ash and mine waste deposits i.e., they perform nitrogen fixation in the atmosphere by using bacteria. Other plants such as Secale cereale, Avena sativa, Hordeum sativum, Triticum aestivum, Dactylis glomerata, Festuca rubra, Poa pratensis, Lolium multiflorum, Lolium perenne, Arrhenatherum elatius, Phleum pretense are important as nursery culture. These species act as pioneers, because they begin the process of revegetation providing erosion control, improve the physicochemical composition of fly ash and mine spoil, retain moisture, and nutritional substances that will be later used by spontaneous colonizers (Mitrović et al., 2008; Maiti, 2013; Gajić et al., 2016).

Over time, plant species that are sown/planted or they spontaneously colonize fly ash and mine waste deposits bind substrate with a fibrous root system, and they spread by seeds and rhizomes forming a dense vegetation cover. In the initial phase of colonization, annual, and biennial plant species are dominant on the disposal. They are characterized by $r$-selection and with them the process of vegetation regeneration begins. According to Grime (1979) biennials can be competitive ruderals (C-R) and stress-tolerant ruderals (S-R). Annual plants have a short life span, rapid growth during the season and large production of seeds (Erigeron, Chenopodium) whereas biennials have a large amount of seeds, life cycle of several years, but they flower and fruit only once, after what they die (Oenothera biennis, Daucus carota, Verbascum phlomoides, Tragopogon dubius). Perennial, herbaceous plants spread and grow from the seeds, rhizomes, stolons, bulbs, and tubers. The rhizomes are used for the accumulation of reserve substances and survival during adverse periods, and serve as a link between the aboveground shoots (Calamagrostis epigejos, Phragmites communis, Festuca rubra, Tussilago farfara, Cirsium arvense, Heliatnhus tuberosus, Epilobium). Perennials can be stress-tolerant ruderals (S-R), stress-tolerant competitors (C-S), competitive ruderals (C-R) and "C-S-R" (Grime, 1979). Trees and shrubs that can grow on fly ash or mine waste deposits are Acacia, Acer, Azadirachta, Albizia, Amorpha, Cassia, Dalbergia, Eucaliptus, Fraxinus, Grevillea, Leucaena, Melia azedarach, Morus, Platanus, Pongamia pinnata, Populus, Phyllanthus emblica, Rosa, Rubus, Salix, Tamarix, Tectona grandis (Cheung et al., 2000; Maiti, 2013; Gajić and Pavlović, 2018; Gajić et al., in press). These plant species are characterized by K-selection because they have long-life cycle and slow growth with high assimilates investment in vegetative growth. Trees and shrubs can be competitors (C), stress-tolerant competitors (C-S), and stress tolerators (S) (Grime, 1979).

\section{VEGETATION SURVEYS ON FLY ASH AND MINE WASTE DEPOSITS}

Floristic composition of plant species on fly ash and mine waste deposits provides insight into the environmental and floristic potential of these sites in the process of biological recultivation and primary and secondary succession (Nikolić et al., 2014; Randjelović et al., 2014; Pandey et al., 2015a; Gajić and Pavlović, 2018) (Figures 1, 2). Vegetation surveys showed that a large number of plant species that are sown or spontaneously colonized these degraded sites belong to the families Fabaceae, Poaceae, Asteraceae, Chenopodiacea, Brassicaceae, Rosaceae (Li et al., 2007; Pandey et al., 2015b; Gajić et al., in press).

The plant species that are tolerant to adverse conditions on fly ash deposits in Europe are Achillea millefolium, Agrostis capillaries, Calamagrostis epigejos, Chenopodium rubrum, Cirsium arvense, Crepis setosa, Cynodon dactylon, Dactylis glomerata, Daucus carota, Echium vulgare, Erigeron canadensis, Eqiuisetum sp., Epilobium hirsutum, Festuca rubra, Hypericum perforatum, Linaria vulgaris, Lolium perenne, Lotus corniculatus, Medicago sativa, Melilotus officinalis, Oenothera biennis, Phragmites communis, Plantago lanceolata, Reseda lutea, Rumex acetosella, Polygonum lapathiholium, Pycreus glomeratus, Sonchus arvensis, Sysimbrium orientale Rumex obtusifolia, Salsola kali, Silene vulgaris, Sinapis arvensis, Solidago serotina, Senecio vulgaris, Sonchus oleraceus, Sorghum halepense, Trifolium repens, Tussilgo farfara, Vicia villosa, Verbascum phlomoides, Xantium strumarium, Acer pseudoplatanus, Amorpha fruticosa, Gleditschia triacanthos, Eleagnus angustifolia, Morus alba, Morus nigra, Robinia pseudoaccacia, Rosa canina, Rubus caesisus, Populus alba, Salix alba, and Tamarix tetandra (Hodgson and Townsend, 1973; Mulhern et al., 1989; Shaw, 1996; Djordjević-Miloradović, 1998; Pavlović et al., 2004; Djurdjević et al., 2006; Mitrović et al., 2008; Gajić and Pavlović, 2018; Gajić et al., in press) (Table 2). Furthermore, in India different plant herbaceous species colonize fly ash deposits: Amaranthus deflexus, Calotropis procera, Cannabis sativa, Cassia tora, Chenopodium album, Croton bonplandium, Cynodon dactylon, Eclipta alba, Limnanthe, Ipomea carnea, Parthenium hysterophorus, Saccharum bengalense, Sacharum munja, Saccharum spontaneum, Sida cordifolia, Solanum nigrum, Thelypteris dentate, Typha latifolia (Dwivedi et al., 2008; Gupta and Sinha, 2008; Maiti and Jaiswal, 2008; Pandey and Singh, 2014; Pandey, 2015; Pandey et al., 2015b, 2016a; Kumari et al., 2016) (Table 2). In Hong Kong, plant species that can grow on fly ash deposits are Eleusine indica, Neyraudia reynaudiana, Tamarix chinensis, Chenopodium acuminatum, Fimbristylis polytrichoides, Pteridium aquiilinum, Panicum repens (Chu, 2008) whereas, in Australia plants with high ecological potential to grow on fly ash deposits are Atriplex, Enchylaena tomentosa, Halosarcia, Mesembryanthemum, Nitraria billardieri and Scaevola colloris (Jusaitis and Pillman, 1997) (Table 2). Vegetation surveys on fly ash deposits in South Africa showed the following plant species: Amaranthus hybridus, Chamaecrista bienis, Chloris gayana, Cynodon dactylon, Cyperus esculentus, Digitaria 


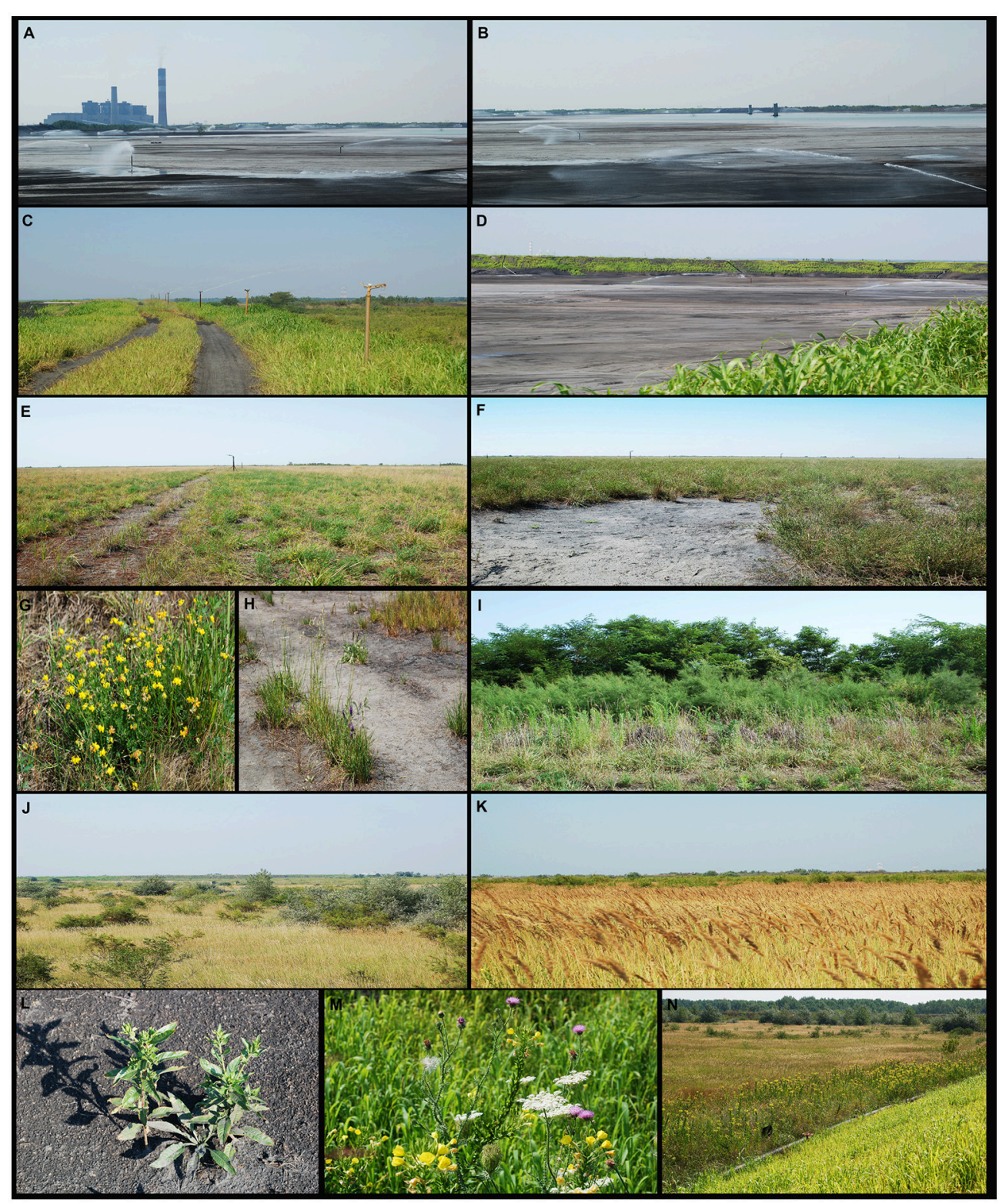

FIGURE 1 | Fly ash deposits at the thermoelectric plant station "Nikola Tesla-A" (TENT-A) in Obrenovac (Serbia): active cassette of fly ash (A-D); passive cassette of fly ash 3 years after biorecultivation with sown legumes, grassses, and shrubs (E-I); passive cassette of fly ash 11 years after biorecultivation with spontaneous colonizers (J-N).

eriantha, Eragrostis sp., Hyparrhenia hirta, Lepidium bonariensis, Lespedeza cunea, Brachiaria serrata, Heteropogon contortus, Tristachya leucothrix, Setaria sphacelata (Morgenthal et al., 2001; Van Rensburg et al., 2003) (Table 2).

Plant species that have high capacity to grow and survive in mining areas are Agrostis stolonifera, Calamagrostis epigejos, Cerastium arvense, Polygonum aviculare, and Tussilago farfara in flotation tailings from $\mathrm{Cu}$ ore in Poland (Kasowska et al., 2018); Agrostis capillaries, Rumex acetosella, Vicia hirsute, Apera spica-venti, Chenopodium botrys, Xantium italicum, Equisetum palustre, Persicaria lapathifolia, Vulpia myuros, Polygonum lapathifolia, Betula pendula, Populus tremula, Populus alba, and Populus nigra in in Timok River floodplain that are partially damaged by slurry sulphidic waste from $\mathrm{Cu}$ mine in Bor in Serbia (Nikolić et al., 2014, 2016); Agrostis stolonifera, Epilobium dodonaei, Calamagrostis epigejos, and Centaurea arenaria on non-reclaimed overburden sites, Robinia pseudoacacia, Cirsium eriophorum, Festuca valeisaca, Linaria genistifolia, Taraxacum offinale, Convolvulus arvensis, Achillea millefolium, Vicia cracca, Daucus carota, Centaurea stoebe Poa pratensis, and Rumex crispus on reclaimed overburden in $\mathrm{Cu}$ mine in Bor in Serbia (Randjelović et al., 2014, 2016); Dittrichia viscosa, 

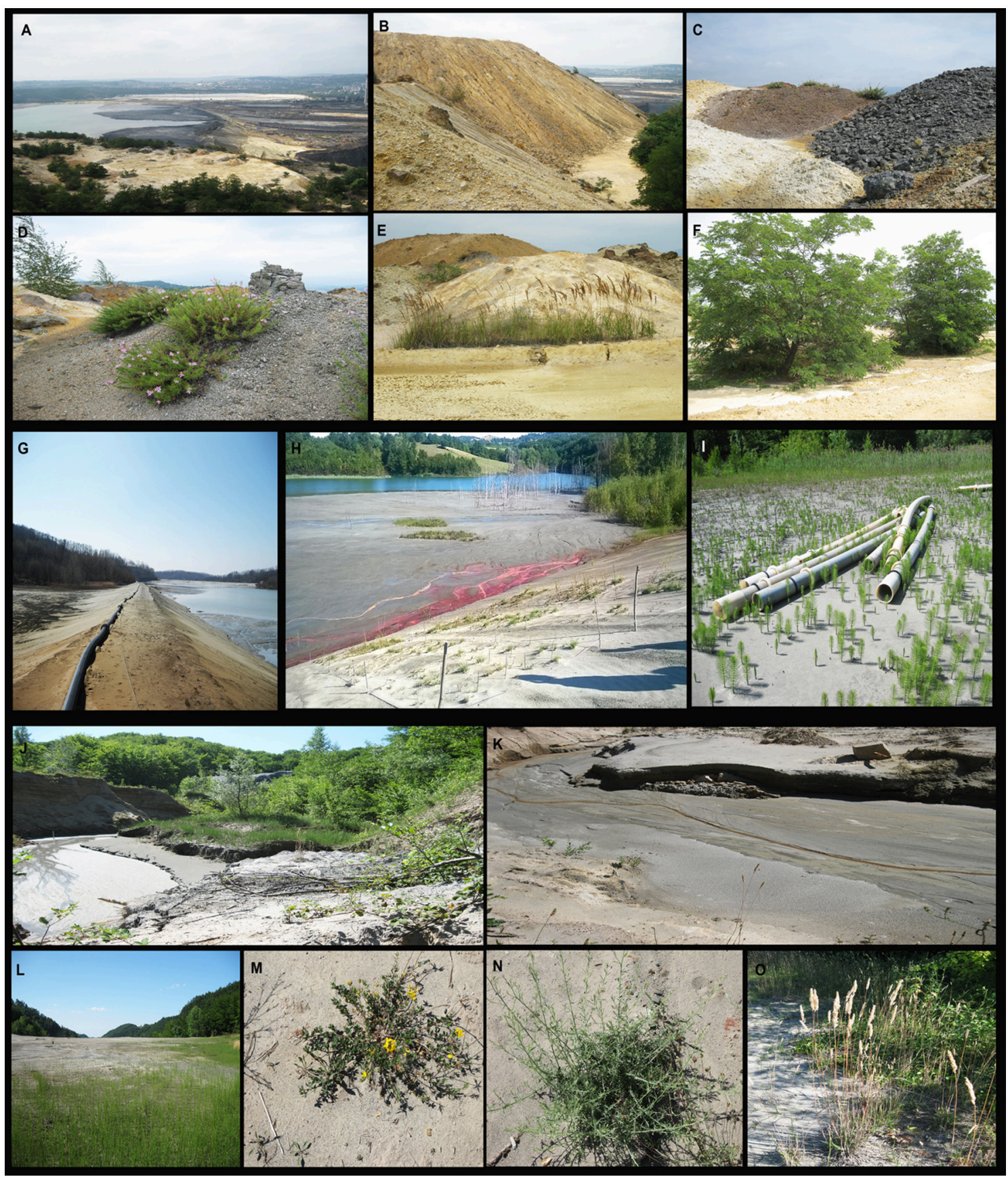

FIGURE 2 | Mine waste in Serbia: copper mine waste in metalliferous Bor region (A-C) with Epilobium dodonaei (D), Calamagrostis epigejos (E), and Robinia pseudoaccacia (F); mine flotation tailings at the Pb/Cu/Zn mine "Rudnik" (G-H) with spontaneously colonized Equisetum sp. (I); antimony flotation tailings "Stolice" after accidental flooding event with spontaneously colonized plant species 1 year later $\mathbf{( J - O ) . ~}$

Cistus salviifolius and Euphorbia pithyusa in mining tailings in Sardinia (Jimenez et al., 2011); Digitalis purpurea, Mentha suavolens, and Ruscus ulmifolius in abandoned $\mathrm{Pb}$ mine in Portugal (Pratas et al., 2013); Zygophyllum fabago, Helichrysum decumbens, Tamarix, Lygeum spartum, Piptatherum miliaceum, Pinus halepensis, Tetraclinis articulate in Cartagena-La Union mining district, Spain (Conesa et al., 2006; Parraga-Aguado et al., 2014); Coincya monensis, Agrostis durieui, Holcus lanatus, Festuca rubra, Dactylis glomerata, Cytisus striatus, Genista legionensis, Lotus corniculatus in $\mathrm{Pb}-\mathrm{Zn}$ and $\mathrm{Hg}$-As mining waste in Spain (Fernandez et al., 2017); Pistacia, terebinhtus, Cistus creticus, Pinus brutia, and Bosea cypria in $\mathrm{Cu}$ containing 
mine tailings in Cyprus (Johansson et al., 2005); Ricinus communis in mine tailings, Mexico (Ruiz Olivares et al., 2013); Amaranthus watsonii, Solanum lumholtyianum, Bromus catharticus, Acacia farnesiana, Gnaphalium leucocephalum, Brickellia coulteri, Baccharis sarothoides, Prosopis velutina, Boerhavia coulteri from abandoned mine tailings, Sonora, Mexico (Santos et al., 2017); Salsola collina, Festuca elata, Medicago sativa, Ipomea purpurea, Grewia biloba, Cotinus coggygria, Zizipus jujube, Vitex negundo, Bidens parvifloa, Sonchus oleraceus, Artemisia annua and Carex tristachya on soilrock mixture in abandoned mines in Beijing in China (Zhang et al., 2014); Digitaria sanguinalis, Erigeron canadensis, Phytolaca acinosa, Pteris multifida, Cynodon dactylon, and Melastoma dodecandrum in Mn mineland in China (Li et al., 2007) (Table 2).

\section{PHYTOREMEDIATION-GENERAL ASPECTS}

Phytoremediation presents an efficient, "green clean," environmental, low cost, and eco-friendly technology that uses plants to reduce or remove inorganic and organic pollutants from environment (Raskin et al., 1997; Salt et al., 1998; McCutcheon and Schnoor, 2003; Pilon-Smits and LeDuc, 2009). The term phytoremediation consists of the Greek prefix "phyto" which means "plant" and the Latin suffix "remedium" which means "renew, able to cure or restore" (Raskin et al., 1997). The main phytoremediation technologies are phytostabilization and phytoextraction, rhizodegradation/phytostimulation and phytodegradation/phytotransformation (Raskin et al., 1997; Salt et al., 1998; McCutcheon and Schnoor, 2003; Pilon-Smits and LeDuc, 2009) (Figure 3A).

Phytostabilization is a phytoremediation technology which uses plants to reduce the mobility and bioavailability of metal(loid)s and organic pollutants in the surrounding environment preventing their migration in the soil and groundwater or their entry into the food web (Nwoko, 2010). In addition, phytostabilization improves the physico-chemical characteristics of the polluted substrate by increasing the content of organic matter and nutrient levels and preventing wind erosion. This can be achieved by using plant species that are named "excluders," which are capable to limit the uptake of pollutants in high concentrations inside the plant tissue over a wide range of soil concentrations i.e., they immobilize pollutants in the substrate or in plant roots (Baker, 1981). The main mechanisms of phystostabilization are avoiding or excluding the pollutant from further transport at the root level by binding to the cell wall and/or preventing the transport through the plasma membrane, by the presence of mycorrhizal fungi and the presence of root exudates in the rhizosphere (Pilon-Smits and LeDuc, 2009).

Phytoextraction is a phytoremediation technology that uses plants capable of accumulating metal(loid)s in the roots and aerial parts of the plants (Reeves and Baker, 2000). This phytoremediation technique uses accumulators/hyperaccumulators because these plants survive regardless of excess concentration of metal(loid)s in their above-ground tissues. Therefore, plants suitable for phytoexctraction should have fast growth, high biomass, extended root system, high root-shoot transfer and good tolerance to high concentrations of metal(loid)s in the plant tissue (Tong et al., 2004). Generally, hyperaccumulators are not popular for phytoremediation due to slow growth rate and low biomass (Pilon-Smits and LeDuc, 2009). Uptake of pollutants from the environment and their accumulation is achieved through the formation of chelates and sequestration of the metal(loid)s in the vacuole of roots and leaves (Kidd et al., 2009).

Rhizodegradation/phytostimulation is phytoremediation technology that uses roots of plants which enhance microbial and fungal activity in the rhizosphere and breakdown organic pollutants (polycyclic aromatic hydrocarbons, PAHs and polychlorinated biphenyls, PCBs) (Pilon-Smits and LeDuc, 2009; Ma et al., 2011). According to Pilon-Smits and LeDuc (2009) suitable plant species should have large and dense root systems and rhizobacterial strains. Therefore, plants facilitate degradation of organic pollutants by stimulating microbial and fungal activity releasing exudes (organic acids, sugars, amino acids, phenolics, and enzymes dehalogenase, nitroreductase, peroxidase, laccase) (Ma et al., 2011). Stimulation of soil microbial communities by root exudates provides acquisition of nutrients, changes of $\mathrm{pH}$, water flux, availability of oxygen around roots and root growth (Ahemad and Kibret, 2014; Kala, 2014). Plant growth promoting bacteria (PGPB) present a consortium of bacteria that colonize different niches of plant roots and they can degrade pollutants more efficiently than a single species/strain (Kuiper et al., 2004). Rhizobacteria, such as Achromobacter, Arthrobacter, Azotobacter, Azospirillum, Bacillus, Enterobacter, Pseudomonas, Serratia, and Streptomyces have been found to have beneficial effects on plant species in metal-contaminated environments because they can reduce the metal toxicity by biosorption and bioaccumulation (Tokala et al., 2002; Dimpka et al., 2009).

Phytodegradation / phytotransformation is a phytoremediation technology which implies degradation of organic compounds by plant enzymes within roots or leaves to simple molecules, such as $\mathrm{CO}_{2}$ and $\mathrm{H}_{2} \mathrm{O}$ (Burken, 2003; Pilon-Smits and LeDuc, 2009). The network of detoxification, degradation and storage of organic compounds in plants can be divided into three steps: (a) transformation (activation and transformation of organic compounds); (b) conjugation process which occurs between organic compounds and malonic acid, Dglucose, glutathione, and amino acids where conjugates become less mobile and less toxic; (ac) storage/elimination (sequestration or storage of organic compounds in cell vacuole, apoplast, or cell walls) (Burken, 2003). This cascade of metabolic reactions is also named the "green liver model" due to its similarity to the mammalian metabolism (Sandermann, 1994; Burken, 2003).

\section{UPTAKE, TRANSPORT, TOLERANCE AND CROSS - TALK BETWEEN METAL(LOID)S IN PLANTS}

The uptake of metal(loid)s depends on total and available concentrations, cation exchange capacity, redox potential, $\mathrm{pH}$, 
TABLE 2 | Plant species grown on fly ash deposits and mine waste worldwide.

\section{FLY ASH DEPOSITS}

\section{Europe}

Achillea millefolium, Agrostis capillaries, Calamagrostis epigejos, Chenopodium rubrum, Cirsium arvense, Crepis setosa, Cynodon dactylon, Dactylis glomerata, Daucus carota, Echium vulgare, Erigeron canadensis, Eqiuisetum sp., Epilobium hirsutum, Festuca rubra, Hypericum perforatum, Linaria vulgaris, Lolium perenne, Lotus corniculatus, Medicago sativa, Melilotus officinalis, Oenothera biennis, Phragmites communis, Plantago lanceolata, Reseda lutea, Rumex acetosella, Polygonum lapathiholium, Pycreus glomeratus, Sonchus arvensis, Sysimbrium orientale Rumex obtusifolia, Salsola kali, Silene vulgaris, Sinapis arvensis, Solidago serotina, Senecio vulgaris, Sonchus oleraceus, Sorghum halepense, Trifolium repens, Tussilgo farfara, Vicia villosa, Verbascum phlomoides, Xantium strumarium, Acer pseudoplatanus, Amorpha fruticosa, Gleditschia triacanthos, Eleagnus angustifolia, Morus alba, Morus nigra, Robinia pseudoaccacia, Rosa canina, Rubus caesisus, Populus alba, Salix alba, Tamarix tetandra

\section{India}

Amaranthus deflexus, Calotropis procera, Cannabis sativa, Cassia tora, Chenopodium album, Croton bonplandium, Cynodon dactylon, Eclipta alba, Limnanthe, Ipomea carnea, Parthenium hysterophorus, Saccharum bengalense, Sacharum munja, Saccharum, spontaneum, Sida cordifolia, Solanum nigrum, Thelypteris dentate, Typha latifolia

\section{Hong kong}

Eleusine indica, Neyraudia reynaudiana, Tamarix chinensis, Chenopodium acuminatum, Fimbristylis polytrichoides, Pteridium, aquiilinum, Panicum repens

\section{Australia}

Atriplex, Enchylaena tomentosa, Halosarcia, Mesembryanthemum, Nitraria billardieri, Scaevola colloris

\section{South Africa}

Amaranthus hybridus, Chamaecrista bienis, Chloris gayana, Cynodon dactylon, Cyperus esculentus, Digitaria eriantha, Eragrostis sp. Hyparrhenia hirta, Lepidium bonariensis, Lespedeza cunea, Brachiaria serrata, Heteropogon contortus, Tristachya leucothrix, Setaria sphacelata

\section{MINE WASTE}

\section{Poland}

Agrostis stolonifera, Calamagrostis epigejos, Cerastium arvense, Polygonum aviculareTussilago farfara

\section{Serbia}

Agrostis capillaries, Rumex acetosella, Vicia hirsute, Apera spica-venti, Chenopodium botrys, Xantium italicum, Equisetum palustre, Persicaria lapathifolia, Vulpia myuros, Polygonum lapathifolia, Betula pendula, Populus tremula, Populus alba, Populus nigra, Agrostis stolonifera, Epilobium dodonaei, Calamagrostis epigejos, Centaurea arenaria

\section{Sardinia}

Dittrichia viscosa, Cistus salviifolius, Euphorbia pithyusa

\section{Portugal}

Digitalis purpurea, Mentha suavolens, Ruscus ulmifolius

\section{Spain}

Zygophyllum fabago, Helichrysum decumbens, Tamarix, Lygeum spartum, Piptatherum miliaceum, Pinus halepensis, Tetraclinis articulate, Coincya monensis, Agrostis durieui, Holcus lanatus, Festuca rubra, Dactylis glomerata, Cytisus striatus, Genista legionensis, Lotus corniculatus

\section{Cyprus}

Pistacia, terebinhtus, Cistus creticus, Pinus brutia, Bosea cypria

\section{Mexico}

\section{Ricinus communis}

Amaranthus watsonii, Solanum lumholtyianum, Bromus catharticus, Acacia farnesiana, Gnaphalium leucocephalum, Brickellia coulteri, Baccharis sarothoides, Prosopis velutina, Boerhavia coulteri

\section{China}

Salsola collina, Festuca elata, Medicago sativa, Ipomea purpurea, Grewia biloba, Cotinus coggygria, Zizipus jujube, Vitex negundo, Bidens parvifloa, Sonchus oleraceus, Artemisia annua, Carex tristachya, Digitaria sanguinalis, Erigeron canadensis, Phytolaca acinosa, Pteris multifida, Cynodon dactylon, Melastoma Dodecandrum
Hodgson and Townsend, 1973; Mulhern et al., 1989; Shaw, 1996; Djordjević-Miloradović, 1998; Pavlović et al., 2004; Djurdjević et al., 2006; Mitrović et al., 2008; Gajić and Pavlović, 2018; Gajić et al., in press

Dwivedi et al., 2008; Gupta and Sinha, 2008; Maiti and Jaiswal, 2008; Pandey and Singh, 2014; Pandey, 2015; Pandey et al., 2015b, 2016a; Kumari et al., 2016

Chu, 2008

Jusaitis and Pillman, 1997

Morgenthal et al., 2001;

Van Rensburg et al., 2003
Kasowska et al., 2018

Nikolić et al., 2014, 2016; Randjelović et al., 2014; Randjelović et al., 2016

Jimenez et al., 2011

Pratas et al., 2013

Conesa et al., 2006; Parraga-Aguado et al., 2014; Fernandez et al., 2017

Johansson et al., 2005

Ruiz Olivares et al., 2013

Santos et al., 2017

Zhang et al., 2014

Li et al., 2007 


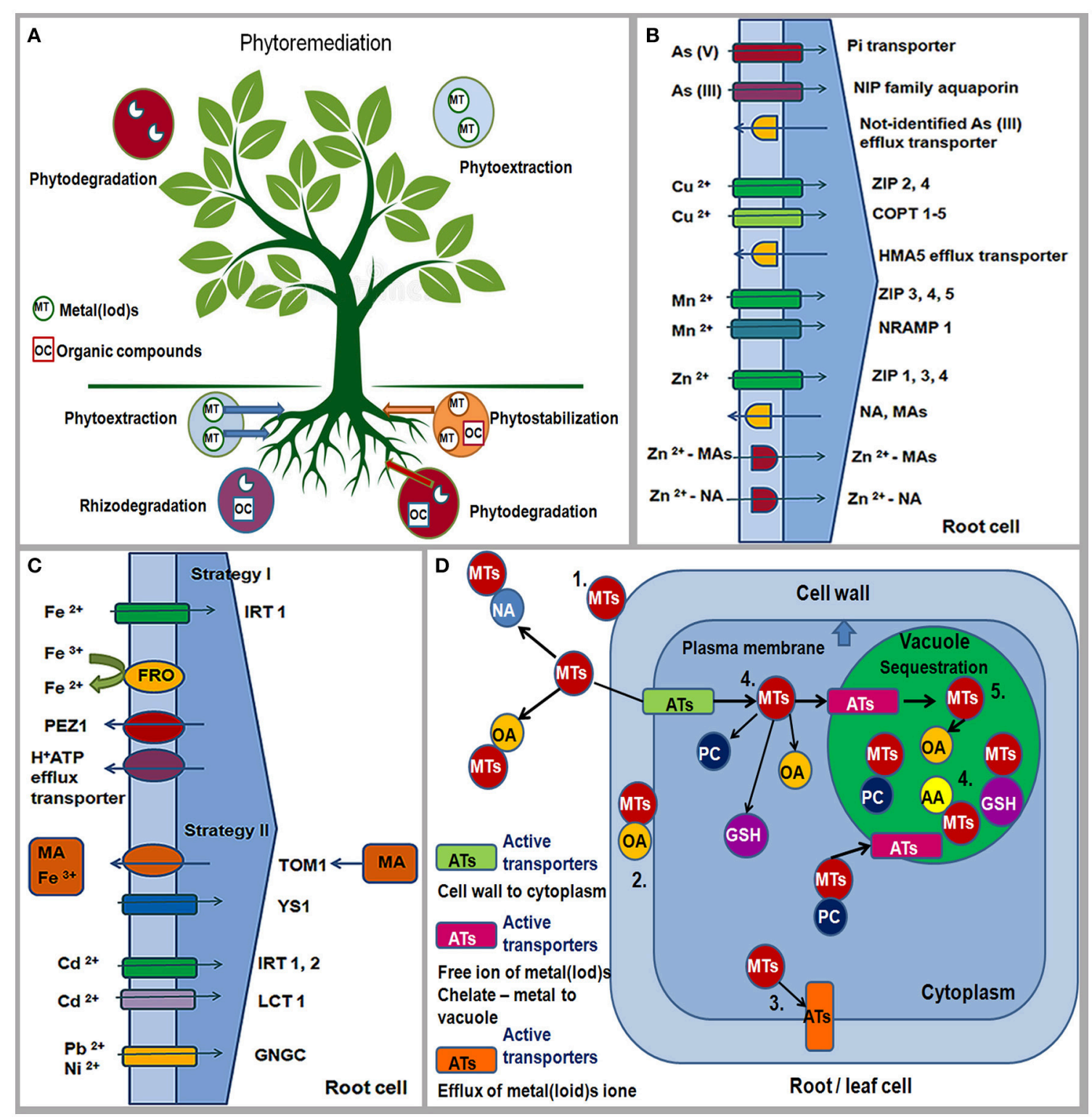

FIGURE 3 | Phytoremediation technologies: Phytostabilization; Phytoextraction; Phytostimulation/Rhizodegradation; Phytodegradation/Phytotransformation. MT, metal(Ioid)s; OC, organic compounds. Pollutants can be stabilized or degraded in the rhizosphere, sequestered or degraded in plant roots and leaves (schema modified from Pilon-Smits and LeDuc, 2009) (A). Strategies for As, Cu, Zn, Mn, Fe, Cd, Ni and Pb uptake by plant roots from soil through different active transporters (ATs); ZIP/IRT, zinc, iron regulated protein; COPT, copper putative transporter; NRAMP, natural resistance -associated macrophage protein; HMA-heavy metal P-type ATPase; $\mathrm{H}^{+}$ATP, HA-proton efflux transporter; FRO-ferric reductase/oxidase; PEZ1, phenolics efflux zero1; TOM1, efflux transporter; YS1, yellow stripe-like1; NA, nicotinamine; MA, family of mugineic acids; LCT1, low-affinity cation transporter; GNGC channels, putative transition metal transporter (schema modified from Hall and Williams, 2003; Clemens, 2006) (B,C); Tolerance mechanisms for metal(loid)s in plants: (1) binding of metal(loid)s to the cell wall, (2) chelate of metal-organic acid on the outside of the cell membrane, (3) active metal efflux from cells, (4) metal-chelator complexes (5) compartmentalization or sequestration in a vacuole; Ats, active transporters; MTs, metal(loids); OA, organic acid; NA, nicotinamine; AA, amino acids; GSH, glutathione; PC, phytochelatines (schema modified from Tong et al., 2004; Pilon-Smits and LeDuc, 2009) (D).

the presence of $\mathrm{Al}, \mathrm{Fe}$ and $\mathrm{Si}$ oxide, organic matter, texture, aeration and moisture of soil, and climatic conditions (KabataPendias, 2011). Adaptive mechanisms of plants that are related to the uptake and translocation of pollutants can be different and they are associated with distribution, redistribution, storage, and detoxification of metal(loid)s in roots and leaves. Adaptive responses of plants to high or low concentrations of chemical elements include changes in the expression of the transporter genes responsible for the uptake, efflux, translocation, and sequestration of elements in plants (Memon and Schröder, 2006). Transport of metal(loid) ions from roots to leaves is performed via membrane transporters, amino acids and/or organic acids 
(Jabeen et al., 2009). The maintenance of metal-ion homeostasis and plant tolerance in plants is enabled by some families of transporters in roots and leaves: a) influx transporters: ZIP/IRT family of proteins (zinc-iron regulated protein permease) and NRAMP protein (natural resistance-associated macrophage protein); b) efflux transporters: HM-ATPase, CDF (cation diffusion facilitator), CAX (cation exchanger) and ABC (ATPbinding cassette transporters) (Yang et al., 2005; Arif et al., 2016; Castro et al., 2018) (Figures 3B,C).

Plant tolerance to deficiency or toxicity of metal(loid)s can be achieved by excluding the element from further course of transport or its accumulation in plant cells (Baker, 1987). The exclusion mechanism is based on the limited absorption and accumulation of toxic metal(loid) ions through: (a) increasing their binding capacity to the cell wall, (b) preventing their entry into the cytoplasm and transport through the plasma membrane by reducing the absorption through modification of the ion channels and/or ejection of the metal(loid)s from the cell by active efflux pump, as well as forming from the outer side of the plasma membrane metal—chelate complexes with organic acids (OA) (Tong et al., 2004) (Figure 3D). Tolerance to high metal(loid) concentrations in cell cytoplasm (accumulation) is achieved through: (a) inactivation by forming complexes between different chelate compounds (glutathione, GSH; phytohelatines, PC; organic acids, OA and amino acid, AA) and metal(loid)s; (b) compartmentalization in vacuoles and other cellular organelles (chloroplasts, mitochondria, Golgi apparatus, endoplasmic reticulum) and/or sequestration of metals by chaperones (proteins involved in intracellular transport of metals to the place of activation) (Tong et al., 2004; Anjum et al., 2015; Singh et al., 2016) (Figure 3D).

Therefore, As (V) is taken up through the phosphate transport system (As-Pi) whereas As (III) is adopted by the NIP family of aquaporin proteins (nodulin 26-like protein) (Verbruggen et al., 2009) (Figure 3B). As can be loaded into xylem and transported by the silicon transporter (Lsi2) (Ma et al., 2008). In the cell, As forms a complex with glutathione (As-GSH) that can be transported in a vacuole through an unidentified $\mathrm{ABC}$ transporter or can form a complex with phytochelatines (AsPCs) (Tripathi et al., 2007). In the condition of excess B, BOR2, and BOR4 transporters are accumulated in the plasma membrane of root cells (Miwa et al., 2007; Takano et al., 2007). B can be exported from root cells into xylem reducing $\mathrm{B}$ concentration in roots (Reid, 2014). In roots and leaves, B is bound to the cell wall in the form of B-RGII complex which mitigates boron toxic effects on metabolism and plant growth (Reid and Fitzpatrick, 2009; Reid, 2014). In addition, tonoplast intrinsic protein (TIP), such as AtTIP5;1 localized to the vacuolar membrane is more expressed under high B condition in leaf tissues (Pang et al., 2010).

Furthermore, $\mathrm{Cu}$ is taken up into the root cells through ZIP2 and ZIP4 transporters and putative copper influx transporters (COPT1), and then transferred into the cell via other transporters, such as COPT3 and COPT5 proteins (Figure 3B), HM-ATPases and chaperones to the vacuole, chloroplast, mitochondria and Golgi complex, where it is sequenced: HMA5 protein is responsible for efflux $\mathrm{Cu}$ from root cells and its loading to xylem; HMA7/RAN1 (responsive-to-antagonist1) is a transporter in roots and leaves that has the role of delivering $\mathrm{Cu}$ to Golgi complex; HMA6/PAA1 transports $\mathrm{Cu}$ to the membrane of chloroplast, and further via chaperones (CCs) to $\mathrm{Cu} / \mathrm{Zn}$ SOD; HMA8/PAA2 protein transports $\mathrm{Cu}$ through thylakoid membrane to plastocyanines (PC); COX chaperones deliver $\mathrm{Cu}$ into mitochondria; ATX1 delivers $\mathrm{Cu}$ to HMA5 protein, and $\mathrm{CCH}$ delivers $\mathrm{Cu}$ to Golgi complex (Puig et al., 2007; Yruela, 2009; Migocka and Malas, 2018).

High content of $\mathrm{Mn}$ is taken up by roots through ZRT/IRT1 transporters (Pedas et al., 2005) whereas in the condition of Mn deficiency ZIP3-ZIP7, NRAMP1 and OsNRAMP5 transporters are active (López-Millán et al., 2004; Lanquar et al., 2010; Sasaki et al., 2012) (Figure 3B). In the conditions of Mn deficiency, OsNRAMP5 transporter is also necessary in the accumulation of $\mathrm{Mn}$ in leaves whereas NRAMP3/NRAMP4 proteins transport $\mathrm{Mn}$ in the vacuole of the leaf and they are essential for the maintenance of photosynthetic efficiency (Lanquar et al., 2010). Intracellular transport and accumulation of $\mathrm{Mn}$ and its sequencing in root and leaf cells are achieved through proteins: P-type ATPase transport $\mathrm{Mn}$ into the endoplasmic reticulum (ECA1 - excess Mn, EC3 - Mn deficiency) and Golgi complex (PMR1); MCF family of proteins (mitochondrial carrier family) through chaperone MTM1 transport Mn to MnSOD; Metal $/ \mathrm{H}^{+}$antiporter (CAX2), CDF family of transporters (ShMTP1), and ABC transporters transfer and accumulate $\mathrm{Mn}$ in the vacuole, thereby maintaining the homeostasis of $\mathrm{Mn}$ and providing its optimal amount for the metabolic processes in the plant cells (Wu et al., 2002; Shigaki et al., 2003).

Uptake, transport, intracellular sequencing and maintenance of homeostasis $\mathrm{Zn}$ in plant cells are regulated by numerous membrane transporters and chelating agents (Sinclair and Krämer, 2012; Moreira et al., 2018). In the conditions of $\mathrm{Zn}$ deficiency in Graminae, the secretion of phytosiderophores (mugenic acid families, MAs) is increased whereas in other plants the biosynthesis of nicotinamine (NA) is dominant (Figure 3B). MAs and NA are excreted in the rhizosphere by specific transporters and have a high binding affinity for $\mathrm{Zn}$. Formed $\mathrm{Zn}-\mathrm{MAs}$ and $\mathrm{Zn}-\mathrm{NA}$ complexes are further taken up and transported through the root cell membrane (Sinclair and Krämer, 2012) (Figure 3B). In the conditions of $\mathrm{Zn}$ deficiency, numerous ZRT-IRT transporters are active (ZIP 1, 3 9-12 take up Zn from the soil; IRT3, ZIP4, 5, 8 transport $\mathrm{Zn}$ from root to leaf (Bashir et al., 2012) (Figure 3B). Furthermore, $\mathrm{P}$-type ATPases are responsible for $\mathrm{Zn}$ flow in apoplast and xylem, accumulation of $\mathrm{Zn}$ in plastids and its sequencing in the vacuole (HMA2 and HMA4 transport $\mathrm{Zn}$ from root to leaf, Wong and Cobbett, 2009) and under the condition of high zinc content, HMA1 transporter contributes to the detoxification of $\mathrm{Zn}$ in chloroplast (Kim et al., 2009); CDF family of transporters (Metal Tolerance Proteins such as MTP1, 2, 3) transport $\mathrm{Zn}$ in the vacuole of leaves and roots); MFS family of transporters (Major Facilitator Superfamily of transporters), such as zinc induced facilitator (ZIF1) protein is localized in the tonoplast of the vacuole and is capable of 
transporting organic acid, Zn-organic acid complex, or NA in the vacuole (Haydon et al., 2012); amino acid histidine and organic acids can form $\mathrm{Zn}$ complexes ( $\mathrm{Zn}$-histidine, $\mathrm{Zn}$ - malate and $\mathrm{Zn}$-citrate) in cytoplasm and the vacuole of roots and leaves (Sinclair and Krämer, 2012) whereas PCR2 (cysteinrich protein) exports $\mathrm{Zn}$ from root to leaves (Song et al., 2010).

Fe acquisition mechanisms are different in dicotyledonous (Strategy I) and graminaceous plants (Strategy II) (Kobayashi and Nishizawa, 2012; Nikolić and Pavlović, 2018; Tripathi et al., 2018). In Strategy I, plants acidify the soil and reduce $\mathrm{Fe}^{3+}$ to soluble form $\mathrm{Fe}^{2+}$ that is transported across the root plasma membrane through ferric reductase oxidase 2 (FRO2) and 3 (FRO3) transporters (Mukherjee et al., 2006) (Figure 3C). Fe uptake by roots also occurs through the IRT1 transporter (Hall and Williams, 2003) (Figure 3C). Excretion of proton $\left(\mathrm{H}^{+}\right.$-ATPase i.e., HA-proton efflux transporter) and phenolic compounds from roots to rhizosphere (phenolics efflux transporter, PEZ1, PHENOLICS EFFLUX ZERO 1) may increase the solubility of $\mathrm{Fe}$ ions or support the reducing capacity of $\mathrm{Fe}$ on the root surface (Ishimaru et al., 2011) (Figure 3C). In Strategy II, graminaceous plant response includes secretion of MAs; efflux transporter TOM1 (Nozoye et al., 2011) in the rhizosphere solubilizes $\mathrm{Fe}^{3+}$ and forms $\mathrm{Fe}^{3+}-\mathrm{MA}$ complex that is taken up into root cells by the YELLOW STRIPE 1 (YS1) and YELLOW STRIPE 1-like (YSL) transporters (Inoue et al., 2009) (Figure 3C). Fe translocation in plants includes chelators such as citrate, NA and MAs (Takahashi et al., 2003; Aoyama et al., 2009). However, Fe can be effluxed into the xylem by AtFPN1/AtIREG1 transporters (ferroportin 1/iron regulated 1, Morrissey et al., 2009) localized in the plasma membrane. Influx transporters, such as YSL family members (YSL1, YSL2, YSL3, YSL15) are responsible for longdistance transport of NA-chelated iron into leaves. Furthermore, TOM1, IRT1, ENA1, ENA2 (nicotianamine 1 and 2) as efflux transporters are also important for $\mathrm{Fe}$ translocation inside the plant. According to Thomine et al. (2003) NRAMP3 and NRAMP4 transporters are significant in long distance metal transport. Fe mobilization in the chloroplast is enabled by FRO6,7 (ferric-chelate reductase oxidase) and MAR1/IREG3 (multiple antibiotic resistance 1 /iron-regulated protein 3 ), that are both localized in envelope membranes (Conte and Walker, 2011); PIC1 protein (chloroplast permease 1) transports Fe across the inner envelope membrane of the chloroplast and regulates its homeostasis (Duy et al., 2007); vacuolar iron transporter 1 (VIT1) is proposed to efflux Fe from cytosol into vacuole (Kim et al., 2006).

Lead $(\mathrm{Pb})$, chromium $(\mathrm{Cr})$, and cadmium $(\mathrm{Cd})$ do not have physiological functions in plants and can be toxic at low concentrations whereas nickel $(\mathrm{Ni})$ is essential and cobalt $(\mathrm{Co})$ is a beneficial microelement for plants (Marschner, 1995). Major transporter system responsible for the uptake of $\mathrm{Fe}^{2+}, \mathrm{Mn}^{2+}$, $\mathrm{Zn}^{2+}, \mathrm{Ca}^{2+}$ is ZIP/IRT, but according to Clemens (2006) the uptake of Cd from soil seems to occur via same transporters due to chemical similarity. Therefore, IRT1, IRT2 can be primarily responsible for $\mathrm{Cd}$ uptake into the root, accumulation and translocation (Nakanishi et al., 2006) (Figure 3C). In addition,
$\mathrm{Cd}^{2+/} \mathrm{H}^{+}$and CAX2 antiporters might be involved in the accumulation of $\mathrm{Cd}$ in the vacuole of the root (Hirshi et al., 2000). The LCT1 (low-affinity cation transporter) is important for the uptake of Cd whereas GNGC channels are permeable for $\mathrm{Ni}$ and $\mathrm{Pb}$ (Hall and Williams, 2003) (Figure 3C). Plants in the condition of $\mathrm{Pb}$ excess and nutrient deficiency activate the same $\mathrm{H}^{+}$/ATPase pumps (Zhang et al., 2011). However, the main pathway by which $\mathrm{Pb}$ enters the roots is $\mathrm{Ca}^{2+}$-permeable channel due to competition between two cations (Pourrut et al., 2011). Furthermore, NRAMP1,3 transporters are able to transport Cd and Co in roots and shoots (Thomine et al., 2000). According to Hall and Williams (2003) HMA1-4 transporters are involved in the efflux and transport of $\mathrm{Co}^{2+} / \mathrm{Cd}^{2+} / \mathrm{Pb}^{2+}$ whereas HMA9 is responsible for the export of $\mathrm{Pb}$ and $\mathrm{Cd}$ from the cell. $\mathrm{ABC}$ transporters (MRPs) are responsible for the $\mathrm{Cd}$ accumulation in the vacuole of the root in the form of chelates PC-Cd and GS-Cd (Bovet et al., 2003); CDF transporters are involved in sequestration of $\mathrm{Cd}, \mathrm{Co}$ and $\mathrm{Ni}$ in the vacuole of leaves (Persans et al., 2001); CBP4 protein shows tolerance to $\mathrm{Ni}$ and hypersensitivity to $\mathrm{Pb}$ and it is responsible for reduced $\mathrm{Ni}$ concentration and increased $\mathrm{Pb}$ content in plant cells (Sunkar et al., 2000). Some magnesium transporters, such as MGT1 show high affinity for $\mathrm{Ni}$ and its transport and accumulation in roots and leaves (Li et al., 2001) whereas DTX1 (protein for Detoxification 1) belongs to MATE family of transporters (multidrug and toxic compound extrusion) and it is capable of detoxifying Cd (Li et al., 2002).

The determination of bioconcentration factor (BCF) and translocation factor (TF) is important for assessing the phytoremediation potential of plants (Yoon et al., 2006) as well as the mechanisms of tolerance and the survival strategy of plants on degraded sites (Baker, 1981). Bioconcentration factor (BCF) defines the relationship between the content of the chemical element in the root and its content in the substrate, providing information about element accumulation in the roots and removal efficiency of the chemical element from the given substrate. Translocation factor (TF) defines the relationship between the content of the chemical element in the leaves and its content in the root providing information about the efficiency of plants to transport metal(loid)s from root to leaves. It is stated that plants having BCF $>1$ and $\mathrm{TF}<1$ show phytostabilization potential (Yoon et al., 2006). In addition, plants with $\mathrm{BCF}<1$ and $\mathrm{TF}$ higher than one as well as BCF and TF $<1$ also show phytostabilization potential. Plants that have all these combinations are excluders, because they possess mechanisms that maintain low uptake of soil-metal contents and small shoot-metal contents. However, plants with $\mathrm{BCF}$ and $\mathrm{TF}>1$ are suitable for phytoexctraction and they are accumulators/hyperaccumulators.

\section{PHYTOREMEDIATION OF FLY ASH DEPOSITS}

Plant species growing on fly ash deposits showed high phytostabilization or phytoextraction potential for different chemical elements (Table 3). Thus, sown species Festuca rubra 
on fly ash deposits can be considered as an excluder suitable for phytostabilization due to limited transport of $\mathrm{As}, \mathrm{Cu}, \mathrm{Mn}$, and $\mathrm{Zn}$ from root to leaves $(\mathrm{BCF}<1, \mathrm{TF}<1)$ in spite of efficient transport of $\mathrm{B}$ in leaves (BCF $<1, \mathrm{TF}>1$ ) (Gajić et al., 2016); Ricinus communis can be considered as a good phytostabilizator of fly ash for $\mathrm{Cd}, \mathrm{Cu}, \mathrm{Ni}, \mathrm{Pb}$, and $\mathrm{Zn}$ due to $\mathrm{BCF}<1$ and $\mathrm{TF}<1$ (Pandey, 2013); Saccharum munja is an excluder plant for Cd, $\mathrm{Cr}, \mathrm{Cu}, \mathrm{Ni}, \mathrm{Pb}, \mathrm{Zn}(\mathrm{BCF}<1, \mathrm{TF}<1), \mathrm{Fe}$ and $\mathrm{Mn}(\mathrm{BCF}<1$, TF > 1) (Pandey et al., 2012) indicated that this plant retained more elements in roots than in leaves or in spite of efficient transport of some elements from root to leaves, this species possesses mechanisms that prevent the uptake of high content of metals in plants; Typha latifolia is a good phytostabilizator for Cd in fly ash $(\mathrm{BCF}<1, \mathrm{TF}<1)$ as well as for $\mathrm{Cr}, \mathrm{Cu}, \mathrm{Ni}, \mathrm{Pb}$, and $\mathrm{Zn}$ $(\mathrm{BCF}<1, \mathrm{TF}>1)$ whereas for $\mathrm{Mn}$ this species can be considered as a good accumulator $(\mathrm{BCF}>1, \mathrm{TF}>1$ ) (Pandey et al., 2014); Ipomea carnea showed high phytostabilization potential for $\mathrm{Cu}$ $(\mathrm{BCF}<1, \mathrm{TF}<1), \mathrm{Ni}, \mathrm{Pb}(\mathrm{BCF}>1, \mathrm{TF}<1)$, $\mathrm{Cr}(\mathrm{BCF}<1$, $\mathrm{TF}>1)$ whereas for $\mathrm{Cd}(\mathrm{BCF}>1$, TF $>1)$ this species can be suitable for phytoextraction (Pandey, 2013); Thelypterys dentate is an excluder plant for $\mathrm{Fe}, \mathrm{Si}(\mathrm{BCF}<1, \mathrm{TF}<1)$ as well as for As, $\mathrm{Cd}, \mathrm{Pb}(\mathrm{BCF}>1$, TF $<1$ ) (Kumari et al., 2013); Sida cardifolia is suitable for phytostabilization because of larger content of Co, $\mathrm{Ni}(\mathrm{BCF}<1, \mathrm{TF}<1)$ and $\mathrm{Pb}(\mathrm{BCF}>1$, $\mathrm{TF}<1)$ in roots than in leaves whereas it is an accumulator for $\mathrm{Cd}, \mathrm{Cr}, \mathrm{Cu}, \mathrm{Fe}, \mathrm{Zn}$ $(\mathrm{BCF}>1, \mathrm{TF}>1$ ) (Gupta and Sinha, 2008); Cynodon dactylon is also an excluder plant suitable for phytostabilization of $\mathrm{Fe}, \mathrm{Ni}$ $(\mathrm{BCF}<1, \mathrm{TF}<1), \mathrm{Pb}(\mathrm{BCF}>1, \mathrm{TF}<1), \mathrm{Cd}, \mathrm{Cu}, \mathrm{Mn}(\mathrm{BCF}<1$, TF > 1) (Kumar et al., 2015) because it maintains low uptake of metal content and relatively small shoot-metal content in plants; Chenopodium album possesses an excluder mechanism for $\mathrm{Cd}$, $\mathrm{Cr}(\mathrm{BCF}>1, \mathrm{TF}<1)$ and $\mathrm{Mn}(\mathrm{BCF}<1, \mathrm{TF}>1)$ which makes it a good candidate for phytostabilization of fly ash whereas for $\mathrm{Co}, \mathrm{Cu}, \mathrm{Fe}, \mathrm{Ni}, \mathrm{Pb}$, and $\mathrm{Zn}(\mathrm{BCF}>1, \mathrm{TF}>1)$ this species can be marked as an accumulator suitable for phytoextraction (Gupta and Sinha, 2008).

Plant species that can grow on fly ash and possess a high rhizomediation potential for organic compounds are Agropyron, Cynodon dactylon, Festuca arundacea, Festuca rubra, Lolium perenne, Lotus corniculatus, Trifolium pretense, Melilotus officinalis, Hellianthus annus (McCutcheon and Schnoor, 2003) (Table 3). Plant promoting bacteria (PGPB) is characteristic for F. arundacea (Huang et al., 2004) whereas Rhizobium leguminosarum was found in L. perenne and T. pretense (Johnson et al., 2005). Bacterial strains that enhance the degradation of PAHs for Sorgum bicolor are Pseudomonas montellili, Bacillus subtilis, B. pumilis, Pseudomonas pseudoalcaligenes and Brevibacterium halotolerans (Duponnois et al., 2006; AbouShanab et al., 2008) (Table 3). In addition, Salix inoculated with Pseudomonas sp., Janthinobacterium lividum, Serratia marcescens, Flavobacterium sp., Streptomyces sp., and Agromyces sp. showed high potential for rhizodegradation of PAHs (Kuffner et al., 2008) (Table 3). Furthermore, Medicago sativa and Lolium perenne show high potential in phytoremediation of $\mathrm{PCB}$ compounds because they enhance the number of microbial populations inoculated by Glomus sp. (arbiscular mycorrhizas, AMF) (Teng et al., 2010; Lu et al., 2014).
Plants that can grow on fly ash deposits and have high potential for phytodegradation of PAHs are Daucus carota (Tao et al., 2004), Festuca arundacea (Gao et al., 2013), Lolium multiflorum, Amaranthus sp., Raphanus sativus, Ipomea sp. (phenanthrene, pyrene, Gao and Zhu, 2004), Sorghum drummondii (Petrová et al., 2017), and Chenopodium rubrum (benzo(a)pyrene, Harms et al., 1977) (Table 3). In addition, plant species that are capable to metabolize the PCBs to the bound residue of cell walls by enzymes UDP-dependent glycosyltransferases (glucose, glucuronic acid) or by peroxidases and polyphenol oxidases (lignin, pectin, hemicelluloses) are Trifolium repens, Triticum aestivum, Hordeum vulgare, Daucus carrota, Atriplex sp., Rosa sp. (Wilken et al., 1995; Kolb and Harms, 2000) (Table 3).

\section{PHYTOREMEDIATION OF MINE WASTE DEPOSITS}

Many plant species growing on mine waste rock and tailings showed great potential for phytoremediation (Table 3). Thus, Cistus ladanifer is suitable for phytostabilization of mining areas and can be considered as an excluder plant for $\mathrm{Al}, \mathrm{Ag}, \mathrm{Ba}, \mathrm{Bi}$, $\mathrm{Sr}$, and Sb (Santos et al., 2016); Ricinus communis is an excluder for $\mathrm{Cd}, \mathrm{Cu}, \mathrm{Mn}, \mathrm{Pb}$, and $\mathrm{Zn}$ in spite of high concentrations of $\mathrm{Mn}$ in shoots (Ruiz Olivares et al., 2013); Coincya monensis is considered as $\mathrm{Zn}$ hyperaccumulator whereas, Holcus lanatus, Festuca rubra, Dactylis glomerata present good excluders of $\mathrm{Hg}$ and $\mathrm{As}$ on the $\mathrm{Pb}-\mathrm{Zn}$ and $\mathrm{Hg}$-As mining area (Fernandez et al., 2017); Polygonum aviculare grown at slightly acid spoil on mine tailings with $\mathrm{Ag}, \mathrm{Au}$, and $\mathrm{Zn}$ accumulated $\mathrm{Zn}$ is near the criteria for hyperaccumulators (Gonzalez and Gonzalez-Chavez, 2006); Epilobium dodonaei for $\mathrm{Cu}, \mathrm{Pb}$, and $\mathrm{Zn}$ (Randjelović et al., 2016), Helichrisum decumbens, Zygophylum fabago and Lygeum spartum for $\mathrm{Pb}, \mathrm{Cu}$, and $\mathrm{Zn}$ (Conesa et al., 2006), Acacia retinoides, Helianthemum syriacum, Pinus halepensis, Teucrium capitatum, and Thymelea hirsuta for As, Cd, Pb, and Zn (GomezRos et al., 2013) and Euphorbia pithysa for $\mathrm{Pb}, \mathrm{Cu}$, and $\mathrm{Zn}$ (Jimenez et al., 2011) showed low element concentrations in shoots despite highly contaminated mine spoils and they are suitable for phytostabilization; Cynodon dactylon and Sorghum halepense are good for phytostabilization of $\mathrm{Pb}-\mathrm{Zn}$ mine waste (Madejon et al., 2002); Ditrichia viscosa can be a phytoextractor for As and Zn (Jimenez et al., 2011; Pistelli et al., 2017); Acer pseudoplatanus, Fraxinus excelsior, Robinia pseudoacacia, and Salix sp. are suitable for phytostabilization of mine waste (Mertens et al., 2007).

Microbial and fungal activity is important for restoration of mine tailings, establishment of plants and biogeochemical cycling (Noyd et al., 1995), particularly in acid mine drainage (Mills, 1985). Microorganisms change the bioavailability of heavy metals, solubilization of minerals in mine tailings, release nutrients, supply them to the plants, and enhance plant growth (Moynahan et al., 2002; Wu et al., 2006). Plant-growth promoting bacteria (PGPB), such as Bacillus arsenicoselenatis, Chryssiogenes arsenates and Sulforospirillum arsenophyllum have a high potential for mobilizing As in mine tailings i.e., they are 
TABLE 3 | Plant species growing on fly ash deposits and mine waste with high potential for phytostabilization, phytoextraction, phytodegradation, and rhizomediation.

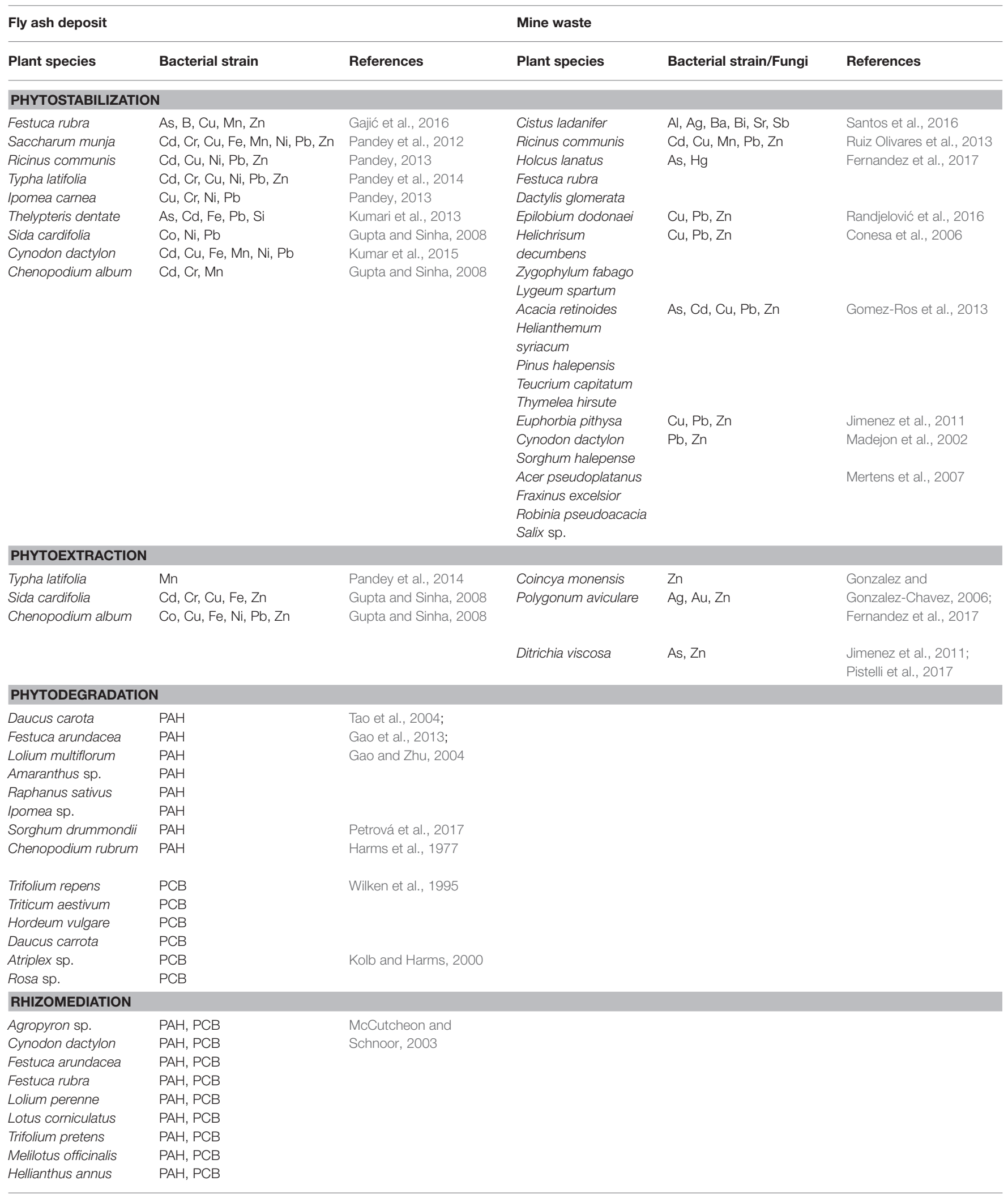


TABLE 3 | Continued

\begin{tabular}{|c|c|c|c|c|c|}
\hline \multicolumn{3}{|l|}{ Fly ash deposit } & \multicolumn{3}{|l|}{ Mine waste } \\
\hline Plant species & Bacterial strain & References & Plant species & Bacterial strain/Fungi & References \\
\hline \multicolumn{6}{|c|}{ PLANT PROMOTING BACTERIA (PGPB)/MYCORRHIZAL FUNGI } \\
\hline $\begin{array}{l}\text { Lolium perenne } \\
\text { Trifolium repens }\end{array}$ & Rhizobium leguminosarum & Johnson et al., 2005 & $\begin{array}{l}\text { Lotus edulis } \\
\text { Lotus ornithopodioides } \\
\text { Elymus repens } \\
\text { Bromus tectorum } \\
\text { Cardaria draba }\end{array}$ & $\begin{array}{l}\text { Variovorax paradoxus5C-2 } \\
+ \text { Mesorhizobium loti Le2 } \\
\text { V. paradoxus 5C-2 + } \\
\text { Sinorhizobium sp. Mc1 } \\
\text { Bacillus megaterium (633) + } \\
\text { Azozobacter chroococum }\end{array}$ & Petrisor et al., 2004 \\
\hline Sorghum bicolor & $\begin{array}{l}\text { Pseudomonas montellili } \\
\text { Bacillus subtilis } \\
\text { Bacillus pumilis } \\
\text { Pseudomonas } \\
\text { pseudoalcaligenes } \\
\text { Brevibacterium halotolerans }\end{array}$ & $\begin{array}{l}\text { Duponnois et al., 2006; } \\
\text { Abou-Shanab et al., } 2008\end{array}$ & $\begin{array}{l}\text { Sedum alfredii }+ \\
\text { Medicago sativa }\end{array}$ & $\begin{array}{l}\text { Phyllobacterium } \\
\text { myrsinacearum RC6b }\end{array}$ & Liu et al., 2015 \\
\hline \multirow[t]{3}{*}{ Salix sp. } & $\begin{array}{l}\text { Pseudomonas sp. } \\
\text { Janthinobacterium lividum }\end{array}$ & Kuffner et al., 2008 & Veronica rechingeri & Glomus sp. & Zarei et al., 2008 \\
\hline & $\begin{array}{l}\text { Serratia marcescens } \\
\text { Flavobacterium sp. } \\
\text { Streptomyces sp. }\end{array}$ & & $\begin{array}{l}\text { Zea mays } \\
\text { Plantago lanceolata }\end{array}$ & Glomus intraradices & Turnau et al., 2012 \\
\hline & Agromyces sp & & $\begin{array}{l}\text { Salsola kali } \\
\text { Panicum virgatum }\end{array}$ & Glomus etunicatum & Johnson, 1998 \\
\hline
\end{tabular}

capable to take up As from substrate and lower its redox state (Macur et al., 2001). Mummey et al. (2002) showed significant enrichment of bacterial, fungal, and total microbial biomass after 20 years of reclamation on surface mines. Different strains of plant growth promoting rhizobacteria were isolated from mine spoils in Lotus sp. (Safranova et al., 2012), Elymus repens, Bromus tectorum, and Cardaria draba (Petrisor et al., 2004) as well as in Sedum alfredii and Medicago sativa (Liu et al., 2015) (Table 3). Mycorrhizal fungi are important for mine remediation and rehabilitation, such as Glomus sp. in Veronica rechingeri growing in $\mathrm{Pb} / \mathrm{Zn}$ mine (Iran, Zarei et al., 2008), Glomus intraradices in Zea mays and Plantago lanceolata growing in $\mathrm{Pb} / \mathrm{Zn}$ mine (Poland, Turnau et al., 2012) as well as Glomus etunicatum in Salsola kali and Panicum virgatum growing in an iron mine site (USA, Johnson, 1998) (Table 3).

\section{CARBON SEQUESTRATION}

Carbon (C) sequestration in soil refers to transferring $\mathrm{CO}_{2}$ from the atmosphere into pedological and plant $\mathrm{C}$ pool in the form of soil inorganic carbon (SIC) that includes elemental $\mathrm{C}$ and carbonate minerals $\left(\mathrm{CaCO}_{3}\right.$ and $\left.\mathrm{MgCO}_{3}\right)$, and organic carbon (SOC) which is stored in plants and organic matter (humus) (Lal et al., 2015). Benefits of terrestrial C sequestration include: (a) mitigation of climatic changes reducing net increase in atmospheric $\mathrm{CO}_{2}$ concentration; (b) restoring soil quality; (c) improving water and nutrient storage capacity and elemental recycling; (d) reducing risk of erosion; (e) improving the environment; (f) increasing biodiversity (Olson et al., 2014; Lal et al., 2015). The SOC pool is the largest terrestrial source of carbon to $3 \mathrm{~m}$ depth (Olson et al.,
2014). A positive SOC budget can be achieved by increasing the input of aboveground (leaves, stems, branches; litter and understory vegetation) and belowground (roots including root exudates) biomass and use of organic fertilizers (compost and manure), and decreasing the loss or output of carbon by erosion, leaching, oxidation, and mineralization (Lal et al., 2015). An important component of the global carbon cycle is soil $\mathrm{CO}_{2}$ flux that represents soil respiration which includes respiration from roots and microbial respiration (Law et al., 2002).

Revegetation of fly ash and reclaimed mine land increases SOC creating large carbon sink capacity which can be used as a potential pool for carbon sequestration (Pandey et al., 2016b; Airhwal and Maiti, 2018). According to Pandey et al. (2016b) the fly ash $\mathrm{CO}_{2}$ flux from vegetated site was higher than from non-vegetated site. However, the $\mathrm{CO}_{2}$ efflux rates were low in Saccharum spontaneum (84.29\%) and Prosopis juliflora (92.09\%) associations released minimum amount of $\mathrm{CO}_{2}$ gas into the atmosphere leading to higher $\mathrm{CO}_{2}$ sequestration. In the same time, the $S$. spontaneum had the highest aboveground and belowground biomass, and high content of organic carbon which can prove that this species is suitable for carbon sequestration. Furthermore, (Airhwal and Maiti, 2018) showed that in 11-years old reclaimed coal mine site $\mathrm{CO}_{2}$ flux was lower $(2.4 \mu \mathrm{mol} \mathrm{CO}$ $\left.\mathrm{m}^{-2} \mathrm{~s}^{-1}\right)$ than in reference to forest soil $\left(3.8 \mu \mathrm{mol} \mathrm{CO} \mathrm{m}^{-2} \mathrm{~s}^{-1}\right)$ due to lower biomass and SOC pool. The $\mathrm{CO}_{2}$ flux from forest soil in China (4.91 $\mu \mathrm{mol} \mathrm{CO}_{2} \mathrm{~m}^{-2} \mathrm{~s}^{-1}$, Sheng et al., 2010) and Europe (Germany, $3.49 \mu \mathrm{mol} \mathrm{CO} 2 \mathrm{~m}^{-2} \mathrm{~s}^{-1}$, Czech Republic, 1,04 $\mu \mathrm{mol} \mathrm{CO} 2 \mathrm{~m}^{-2} \mathrm{~s}-1$, Acosta et al., 2013) was higher than reclaimed coal mine (2.36 $\mu \mathrm{mol} \mathrm{CO} \mathrm{m}^{-2} \mathrm{~s}^{-1}$, Airhwal et al., 2017 and 2.10 $\mu \mathrm{mol} \mathrm{CO} \mathrm{m}^{-2} \mathrm{~s}^{-1}$, Mukhopadhyay and Maiti, 2014). However, 
over time, more carbon is accumulated in plant biomass where in turn more $\mathrm{CO}_{2}$ is sequesterd presenting a win-win option in revegetation planning and phytomanagement of reclaimed sites.

\section{MICOREMEDIATION}

Endophytic non-mycorhizal fungi can promote the remediation of degraded soils due to their regulation of metal(loid)s uptake (Kumar et al., 2018). Therefore, root-colonizing dark septate endophytic fungi (DSE) present conidial or sterile ascomycetes that may occur in contaminated sites protecting plants from metal(loid) stress: Phialophora in Salix caprea $(\mathrm{Pb}, \mathrm{Cd}$, Colpaert et al., 2011) and Hymenoscphus ericae in Pinus (Cu, Zn, Cd mine soil, Utmazian et al., 2007). In addition, DSE are involved in nutrient cycling i.e., they colonize older parts of the roots where nutrients are redistributed from senescent roots into the active roots (Kumar et al., 2018). Furthermore, melanin in the cell wall of DSE hyphae may decrease metal(loid)s toxicity $(\mathrm{Cu}, \mathrm{Zn}, \mathrm{Pb}$, Cd) increasing the activity of antioxidant enzymes (SOD, CAT) which in turn decreases oxidative stress (Zhang et al., 2008; Ban et al., 2012).

\section{PLANT ADAPTIVE RESPONSE TO ENVIRIONMENTAL STRESS}

Integration of plant physiology and ecological restoration provides new perspectives on the relationship between plant physiological response to environmental stress and restoration ecology (Cooke and Suski, 2010). International guideline of the Society for Ecological Restoration provides many potential opportunities for using physiological tools to evaluate the success of restoration plans and projects. Ecophysiological models can be important for understanding processes between environmental stress factors and adaptive response of plants which may help managers for decision-making and assessment of success of different restoration strategies (Cooke and Suski, 2010). In addition, the fundamental understanding of plant physiology and biochemistry is important for selection of appropriate plant species for restoration of degraded sites.

Plant species that grow in the conditions of environmental stresses, such as drought, intense light, high temperature, salt stress, and toxicity/deficiency of metal(loids) show great variation in their mechanisms of tolerance (Gajić et al., 2018). Environmental stressors affect photosynthesis, respiration, water regime and mineral nutrition of plants leading to the production of reactive oxygen species (ROS) causing "oxidative stress" (Mittler, 2002). The maintenance of cell redox homeostasis is achieved by activating the antioxidant plant system that presents a complex of control systems that enable them to overcome stress with minimal damage to the cell structure and function (Foyer and Noctor, 2005; Halliwell, 2006). The balance between ROS production and biosynthesis of antioxidants is very important in controlling redox homeostasis in plant cells (Halliwell, 2006; Foyer and Shigeoka, 2011). Therefore, the efficient removal of ROS can be achieved by activating the non-enzymatic and enzymatic components of antioxidant defense system. The non-enzymatic antioxidants include: carotenoids, $\alpha$-tocopherol, phenolics, prolin, ascorbic acid (AsA), glutathione (GSH), phytochelatins (PCs), metallothionine (MTs). Enzymatic antioxidants include: superoxide dismutase (SOD), ascorbate peroxidase (APX), glutathione reductase (GR), glutathione peroxidase (GPX), catalase (CAT), glutathione S transferase (GST) (Mittler, 2002; Foyer and Noctor, 2005). However, ROS can act as signaling molecules in their adaptive response to stress (Foyer and Noctor, 2005; Foyer and Shigeoka, 2011). Thus, malondialdehyde (MDA) as a product of lipid peroxidation of membranes can act as the buffer of ROS with protective function i.e., it can be a signal for the gene expression of antioxidant enzymes and molecules during the oxidative stress (Weber et al., 2004). Generally, plants are well-adapted to the decreased amount of particular antioxidants inducing a signal for biosynthesis of other components of protection systems (Foyer and Noctor, 2005).

\section{PLANT PHYSIOLOGICAL ADAPTATION ON FLY ASH}

The photosynthetic efficiency of PSII $(\mathrm{Fv} / \mathrm{Fm})$ of plants growing on fly ash deposits were below the optimal range for plants (0.750-0.850, Björkman and Demmig, 1987) which indicates a low number of functionally active PSII reaction centers, photoinhibition of PSII and lower vitality of plants in stress conditions. Low values of $\mathrm{Fv} / \mathrm{Fm}$ were measured in herbaceous plants grown on fly ash deposits, such as Cirsium arvense, Epilobium collinum, Crepis bienis, Eupatorium cannabinum, Verbascum phlomoides, Calamagrostis epigejos, Oenothera biennis, Festuca rubra (0.429-0.691) (Pavlović et al., 2004; Mitrović et al., 2008; Gajić et al., 2013, 2016), as well as in shrubs, such as Tamarix tetandra, Amorpha fruticosa, Spiraea van-houttei (0.588-0.727), and trees Populus alba, Robinia pseudoaccacia (0.541-0.626) (Pavlović et al., 2004; Kostić et al., 2012) (Table 4). However, Festuca rubra growing on fly ash lagoons that are 11 years old showed increased photosynthetic efficiency $(\mathrm{Fv} / \mathrm{Fm})$ indicating that this sown species over time activates adaptive mechanisms that increase the tolerance of the photosynthetic apparatus to stress. Furthermore, plants growing on fly ash deposits showed a high ability to maintain a relatively favorable water balance (Pavlović et al., 2004). Thus, relative water content (RWC) in Spiraea van-houttei, Cirsium arvense, Verbascum phlomoide, Crepis setosa, Epilobium collinum, and Eupatorium cannabinum were in the range 84.03-95.52\% (Pavlović et al., 2004) (Table 4). However, low values of RWC (75.89\%) and high values of water saturation deficit (WSD) (16.40\%) were found in Populus alba (Pavlović et al., 2004) (Table 4). The sap osmotic potential was the most favorable in Crepis setosa, Cirsium arvense and Verbascum phlomoides (from -0.981 MPa to $-1.135 \mathrm{MPa}$ ) whereas in Populus alba unfavorable sap osmotic value was detected ( $-1.377 \mathrm{MPa})$ (Pavlović et al., 2004) (Table 4). 
TABLE 4 | Adaptive physiology of plants growing on fly ash deposits and mine waste.

\begin{tabular}{|c|c|c|}
\hline Plant species & Parameter & References \\
\hline \multicolumn{3}{|l|}{ FLY ASH DEPOSITS } \\
\hline $\begin{array}{l}\text { Calamagrostis epigejos } \\
\text { Cirsium arvense } \\
\text { Crepis bienis } \\
\text { Epilobium collinum } \\
\text { Eupathorium cannabinum } \\
\text { Festuca rubra } \\
\text { Oenothera biennis } \\
\text { Verbascum phlomoides } \\
\text { Amorpha fruticosa } \\
\text { Populus alba } \\
\text { Robinia pseudoaccacia } \\
\text { Spiraea van-houttei } \\
\text { Tamarix tetandra }\end{array}$ & $\mathrm{Fv} / \mathrm{Fm}$ & $\begin{array}{l}\text { Pavlović et al., 2004; } \\
\text { Mitrović et al., 2008; } \\
\text { Gajić et al., 2013; } \\
\text { Gajić et al., } 2016 \\
\text { Kostić et al., } 2012\end{array}$ \\
\hline $\begin{array}{l}\text { Cirsium arvense } \\
\text { Crepis bienis } \\
\text { Epilobium collinum } \\
\text { Eupathorium cannabinum } \\
\text { Verbascum phlomoides } \\
\text { Populus alba } \\
\text { Spiraea van-houttei }\end{array}$ & $\begin{array}{l}\text { RWC, WSD } \\
\text { Osmotic potential }\end{array}$ & Pavlović et al., 2004 \\
\hline $\begin{array}{l}\text { Festuca rubra } \\
\text { Ricinus communis } \\
\text { Typha latifolia } \\
\text { Thelypteris dentate } \\
\text { Cicer arietinum } \\
\text { Lolium perenne }\end{array}$ & $\begin{array}{l}\text { Chlorophylls } \\
\text { Carotenoids }\end{array}$ & $\begin{array}{l}\text { Gajić et al., } 2016 \\
\text { Pandey, } 2013 \\
\text { Pandey et al., } 2014 \\
\text { Kumari et al., } 2013 \\
\text { Pandey et al., } 2010 \\
\text { Lopareva-Pohu et al., } 2011\end{array}$ \\
\hline $\begin{array}{l}\text { Festuca rubra } \\
\text { Cicer arietinum } \\
\text { Thelypteris dentate }\end{array}$ & MDA & $\begin{array}{l}\text { Gajić et al., } 2016 \\
\text { Pandey et al., } 2010 \\
\text { Kumari et al., } 2013\end{array}$ \\
\hline $\begin{array}{l}\text { Calamagrostis epigejos } \\
\text { Festuca rubra } \\
\text { Oenothera biennis } \\
\text { Cicer arietinum } \\
\text { Thelypteris dentate } \\
\text { Oryza sativa } \\
\text { Beta vulgaris } \\
\text { Sesbania cannabina }\end{array}$ & $\begin{array}{l}\text { Phenolics, AsA, DPPH } \\
\text { SOD, POD, CAT, GR, } \\
\text { GST } \\
\text { Cys, NP-SH } \\
\text { Phenolics, AsA, prolin, } \\
\text { Cys, NP-SH }\end{array}$ & $\begin{array}{l}\text { Gajić et al., 2013; } \\
\text { Gajić et al., 2016 } \\
\text { Pandey et al., } 2010 \\
\text { Kumari et al., } 2013 \\
\text { Dwivedi et al., } 2007 \\
\text { Sinha and Gupta, 2005; } \\
\text { Singh et al., } 2008\end{array}$ \\
\hline \multicolumn{3}{|l|}{ MINE WASTE } \\
\hline $\begin{array}{l}\text { Arrhenatherum elatium } \\
\text { Sonchus transcaspicus }\end{array}$ & $\mathrm{Fv} / \mathrm{Fm}$ & Lu et al., 2013 \\
\hline Epilobium dodonaei & $\begin{array}{l}\text { Chlorophylls, } \\
\text { Carotenoids }\end{array}$ & Randjelović et al., 2016 \\
\hline $\begin{array}{l}\text { Zygophylum fabago } \\
\text { Dittrichia viscose } \\
\text { Epilobium dodonaei } \\
\text { Arrhenatherum elatium } \\
\text { Sonchus transcaspicus }\end{array}$ & $\begin{array}{l}\text { MDA, } \mathrm{H}_{2} \mathrm{O}_{2}, \mathrm{O}_{2} \cdot- \\
\text { ROS } \\
\text { MDA } \\
\text { MDA }\end{array}$ & $\begin{array}{l}\text { Lopez-Orenes et al., } 2017 \\
\text { Lopez-Orenes et al., } 2018 \\
\text { Randjelović et al., } 2016 \\
\text { Lu et al., } 2013\end{array}$ \\
\hline Zygophylum fabago & $\begin{array}{l}\text { Phenolics, Proline, AsA, } \\
\text { GSH, NPT, sugars, } \\
\text { iPRX, PALs, PRX, } \\
\text { DPPH }\end{array}$ & Lopez-Orenes et al., 2017 \\
\hline Dittrichia viscose & $\begin{array}{l}\text { Phenolics, AsA, GSH, } \\
\text { sugars, PAL, sPRX, } \\
\text { DPPH }\end{array}$ & Lopez-Orenes et al., 2018 \\
\hline $\begin{array}{l}\text { Epilobium dodonaei } \\
\text { Arrhenatherum elatium } \\
\text { Sonchus transcaspicus }\end{array}$ & $\begin{array}{l}\text { Phenolics, DPPH } \\
\text { SOD, POD, CAT, APX }\end{array}$ & $\begin{array}{l}\text { Randjelović et al., } 2016 \\
\text { Lu et al., } 2013\end{array}$ \\
\hline $\begin{array}{l}\text { Cardaminopsis arenosa } \\
\text { Plantago lanceolata }\end{array}$ & $\begin{array}{l}\text { SOD, POD, GSH, } \\
\text { NP-SH, proline }\end{array}$ & $\begin{array}{l}\text { Nadgorska-Socha et al., } \\
2013\end{array}$ \\
\hline
\end{tabular}

Decrease of chlorophylls and carotenoids content in plants growing on fly ash deposits were noted in Ricinus communis, Typha latifolia, Thelypteris dentate, Festuca rubra,
Amorpha fruticosa, Tamarix tetandra, Populus alba and Robinia pseudoaccacia (Kostić et al., 2012; Kumari et al., 2013; Pandey, 2013; Pandey et al., 2014; Gajić et al., 2016) in relation to control (Table 4). Furthermore, in Cicer arietinum which grew in fly ash treated soils, the content of chlorophylls decreased at 50 and $100 \%$ fly ash whereas carotenoids amount increased (Pandey et al., 2010) (Table 4). Similarly, chlorophyls and carotenoids content decreased in leaves of Lolium perenne growing on the soil where fly ash was added (Lopareva-Pohu et al., 2011). Small content of chlorophylls and carotenoids in plant leaves indicates that the photosynthetic pigments are sensitive to stress factors that prevail on fly ash, such as high temperature, drought, toxic concentrations of $\mathrm{As}, \mathrm{B}, \mathrm{Cd}, \mathrm{Cr}, \mathrm{Pb}$, and the small amount of $\mathrm{Cu}, \mathrm{Mn}$, and $\mathrm{Zn}$ in leaves (Hajibold and Amirazad, 2010; Cervilla et al., 2012; Gajić et al., 2016). However, displacement of $\mathrm{Mg}$ in the structure of chlorophyll molecule with toxic metal(loid) ions due to similar chemical properties reduces its activity and leads to the non-functional molecule (Van Assche and Clijsters, 1990). In addition, small content of carotenoids in plants may suggest decreased photoprotection of the PSII which in turn leads to the reduction of photosynthetic efficiency (Gajić et al., 2016). Malondialdehyde (MDA) as an indicator of free radical production and lipid peroxidation of membranes indicates "oxidative stress" in plants (Weber et al., 2004). It was noted that MDA content in the roots and leaves of Cicer arietinum growing at 50 and $100 \%$ fly ash was high (Pandey et al., 2010) as well as in the roots and fronds of Thelypteris dentate at 75 and $100 \%$ fly ash (Kumari et al., 2013) (Table 4). According to Gajić et al. (2016) in the leaves of Festuca rubra grown on fly ash deposits (Table 4), the content of MDA was high probably as a result of toxic concentrations of $\mathrm{As}$ and $\mathrm{B}$ and the low content of $\mathrm{Cu}, \mathrm{Zn}$, and Mn.

Plant species that grow in the stress conditions prevailing on fly ash promote biosynthesis of antioxidants which can reduce the ROS leading to an increase in photosynthetic efficiency (Gajić et al., 2009, 2016; Hajibold and Amirazad, 2010; Kumari et al., 2013). Thus, in the leaves of sown species Festuca rubra and spontaneously colonized species Calamagrostis epigejos and Oenothera biennis growing on fly ash deposits, increased content of phenolics, ascorbic acids and radical scavenging activity were noted (Gajić et al., 2013, 2016) (Table 4). Furthermore, increased activity of superoxide dismutase (SOD), catalases (CAT), peroxidases (POD), glutathione reductase (GR), and glutathione S-transferase (GST) in Cicer arietinum growing at $50 \%$ and $100 \%$ fly ash were noted (Pandey et al., 2010) as well as increased content of cysteine and non-protein thiols (NP-SH) in Thelypteris dentate (Kumari et al., 2013) and Oryza sativa (Dwivedi et al., 2007) (Table 4). Other authors also showed that in experimental conditions with different levels of fly ash application, content of ascorbic acids, phenolics, prolin, cysteine, and NP-SH in the leaves of Beta vulgaris and Sesbania cannabina increased (Sinha and Gupta, 2005; Singh et al., 2008) (Table 4). Increased biosynthesis of antioxidants in plant species that can grow on fly ash indicates that they possess a high ecophysiological adaptive potential to endure harsh conditions prevailing on fly ash deposits. 


\section{PLANT PHYSIOLOGICAL ADAPTATION ON MINE WASTE}

Plant physiological and biochemical response to multiple stresses on mine waste rock and tailings may indicate their capacity to thrive under extreme environmental conditions (Table 4). The knowledge related to plant metabolite response can be useful for mine land reclamation programs. Thus, changes in antioxidative/oxidative parameters in Zygophylum fabago growing on mine tailings revealed significant decrease of chlorophylls content, reduction of MDA content, $\mathrm{H}_{2} \mathrm{O}_{2}$ and $\mathrm{O}_{2}^{-}$levels, proline content and the ionically-bound cell wall peroxidases (iPRX) whereas the total antioxidant capacity, particularly content of phenolic compounds (flavonoids, proanthocyanidins, hydroxycinnamic acids), ascorbic acid, GSH, NPT (total non-protein thiol), soluble sugars and activity of PAL (phenylalanine ammonia lyase) as well as activity of soluble peroxidases (sPRX) significantly increased (Lopez-Orenes et al., 2017). Therefore, reduction of oxidative stress is associated with the activation of plant antioxidant system to cope with unforable multielement pollution and harsh climatic conditions on mine tailings. Similarly, in Dittrichia viscose growing on mine tailings, no changes were found in ROS, starch, soluble sugar concentrations, ascorbic acid and GSH content whereas the content of cell wall phenolics, PAL and sPRX activity increased (Lopez-Orenes et al., 2018). Slight reduction in the total antioxidant activity was related to the reduction of soluble phenolics. However, coordination of phenolic compounds in phenypropanoid metabolisms could have a prominent role in the capability of plants to cope with oxidative stress and toxic pollutants in mine areas (Lopez-Orenes et al., 2018). Epilobium dodonaei growing on mine waste rock showed the reduction in chlorophylls and carotenoids amount and great content of MDA (Randjelović et al., 2016). Despite high oxidative stress, this species is capable to promote biosynthesis of soluble and cell-wall phenolics and other free radical scavenging compounds as a response to metal(loid)s stress on mine spoil (Randjelović et al., 2016). Lu et al. (2013) showed that Sonchus transcaspicus had a higher adaptive potential to metal-induced oxidative stress compared to Arrhenatherum elatium growing on mine tailings. Photosynthetic efficiency (Fv/Fm) and chlorophyll content decreased in both plants, but it is more pronounced in A. elatius. MDA content in the roots and leaves of $A$. elatius was high, whereas MDA content in the shoots of $S$. transcaspicus was not affected. Furthermore, in S. transcaspicus activity of SOD, POD, CAT, and APX in the shoots and roots was high. Activity of all these enzymes in the roots of A. elatius was also high, but in the shoots only POD activity was high (Lu et al., 2013). Nadgorska-Socha et al. (2013) found that in Cardaminopsis arenosa and Plantago lanceolata growing in mining areas, activity of SOD, POD, and GSH increased whereas nonprotein-SH group content and proline decreased as a response to metal exposure.

\section{CONCLUSION AND FUTURE OUTLOOK}

Fly ash and mine disposal leads to the pollution of soil, surface and groundwater, dispersion of particles by wind having a negative impact on the surrounding environment and human health. Physico-chemical analysis of fly ash or mine waste rock and tailings showed sandy structure with low fractions of clay, low/high $\mathrm{pH}$ values, high electrical conductivity, small amount of $\mathrm{N}$ and available content of $\mathrm{P}_{2} \mathrm{O}_{5}$ and $\mathrm{K}_{2} \mathrm{O}$, high concentrations of As, B, Cd, Cr, Cu, Fe, Mn, Mo, Ni, Pb, Sb, Se, Zn as well as high content of PAHs and PCBs. Vegetation cover on fly ash and mine waste disposal is important to (a) prevent or minimize erosion by wind, (b) to stabilize the steep slopes on the embankments of lagoons, (c) to decrease mobility and toxicity of contaminants in the environment, (d) to provide organic matter which can bind contaminants. Establishment of native plant species, sowing grasses, and legumes and planting shrubs and trees on these disposal sites is essential for ecorestoration success accelerating the chance for spontaneous colonization of numerous native species. Therefore, selection of native plant species is important in revegetation, long-term stability and resilience of an ecosystem. Furthermore, phytoremediation is emerging "green" technology which uses plants and their associated rhizosphere microorganisms to clean up contaminated sites. The phytoremediation technologies which can be applied on fly ash and mine waste deposits are phytostabilization, rhizodegradation and phytodegradation, and to a lesser extent phytoextraction. Phytoremediation offers many advantages, such as low cost, public acceptance and aesthetic values making it suitable to remediate large contaminated areas.

Generally, there is a gap between researches in laboratories under controlled conditions and a "real field scenario" where plant species grow and survive in a polluted environment. The future prospects in phytomanagement of fly ash deposits and mine waste sites require better knowledge of native species that are the best adapted to local region which is important for maintaining ecosystem services and quality of human life. Studies about plant community structure, functional characteristics of ecosystems, biogeochemical cycles, and natural selection are considered to be significant for ecosystem integrity and resilience. Plant biotechnology includes genetic engineering of plants, rhizospheric microbes and fungi in order to remove inorganic or organic pollutants or decrease their toxicity because they possess a high capacity to accumulate or degrade pollutants. The new genomic technologies may identify novel genes for pollutant remediation. Furthermore, the future directions in the research of plant ecophysiological responses to environmental stresses require involvement of biophysics, physiology, biochemistry, molecular biology, and "omics" tools (genomes, transcriptomes, metabolomes, proteomes). Taken together, knowledge on the genetics, physiology, and biochemistry of plants can offer great prospects for improving phytoremediation technologies and cleanup of polluted environments. All these observations can be useful for the selection of suitable plant species capable to endure the environmental stress in contaminated areas and for 
the development of successful phytomanagement of degraded sites on a global scale.

\section{AUTHOR CONTRIBUTIONS}

GG, LD, and PP designed the manuscript. GG and PP wrote the manuscript. MM, OK, and SJ critically evaluated the manuscript.

\section{REFERENCES}

Abou-Shanab, R. A., Ghanem, K., Ghanem, N., and Al-Kolaibe, A. (2008). The role of bacteria on heavy metal extraction and uptake by plants growing on multi-metal contaminated soils. World J. Microbiol. Biotechnol. 24, 253-262. doi: 10.1007/s11274-007-9464-x

Acosta, M., Pavelka, M., Montagnani, L., et al. (2013). Soil surface $\mathrm{CO}_{2}$ efflux measurements in Norway spruce forests: comparison between four different sites across Europe - from boreal to alpine forest. Geoderma 192, 295-303. doi: 10.1016/j.geoderma.2012.08.027

Adriano, D. C., Page, A. L., Elseewi, A. A., Chang, A. C., and Straugan, I. (1980). Utilization and disposal of fly ash and other coal residues in terrestrial ecosystems: a review. J. Environ. Qual. 9, 333-344. doi: $10.2134 /$ jeq1980.00472425000900030001x

Ahemad, M., and Kibret, M. (2014). Mechanisms and applications of plant growth promoting rhizobacteria: current perspective. J. King Saud Univ. Sci. 26, 1-20. doi: $10.1016 /$ j.jksus.2013.05.001

Airhwal, J., and Maiti, S. K. (2018). "Carbon sequestration and Soil $\mathrm{CO}_{2}$ flux in reclaimed coal mine lands from India", in Bio-Geotechnologies for Mine Site Rehabilitation, eds M. N. V. Prasad, P. J. C. Favas, and S. K. Maiti (Amsterdam: Elsevier), 371-392.

Airhwal, J., Maiti, S. K., and Singh, A. K. (2017). Changes in ecosystem carbon pool and soil $\mathrm{CO}_{2}$ flux following post-mine reclamation in dry tropical environment, India. Sci. Tot. Environ. 583, 153-162. doi: 10.1016/j.scitotenv.2017. 01.043

Anjum, N. A., Hasanuzzaman, M., Hossain, M. A., Thangavel, P., Roychoudhury, A., Gill, S. S., et al. (2015). Jacks of metal/metalloid chelation trade in plants - an overview. Front. Plant Sci. 6:192. doi: 10.3389/fpls.2015. 00192

Aoyama, T., Kobayashi, T., Takahashi, M., Nagasaka, S., Usuda, K., et al. (2009). OsYSL18 is a rice iron(III)-deoxymugineic acid transporter specifically expressed in reproductive organs and phloem of lamina joints. Plant Mol. Biol. 70, 681-692. doi: 10.1007/s11103-009-9500-3

Arif, N., Yadav, V., Singh, S., Singh, S., Ahmad, P., Mishra, R. K., et al. (2016). Influence of high and low levels of plant-beneficial heavy metal ions on plant growth and development. Front. Environ. Sci. 4:69. doi: $10.3389 /$ fenvs.2016.00069

Baker, A. J. M. (1981). Accumulators and excluders - strategies in the response of plants to heavy metals. J. Plant Nutr. 3, 643-654. doi: 10.1080/01904168109362867

Baker, A. J. M. (1987). "Metal tolerance." New Phytol. 106, 93-111.

Ban, Y., Tang, M., Chen, H., Xu, Z., Zhang, H., and Yang, Y. (2012). The response of dark septate endophytes (DSE) to heavy metals in pure clture. PLoS ONE 7:47968. doi: 10.1371/journal.pone.0047968

Bashir, K., Ishimaru, Y., and Nishizawa, N. K. (2012). Molecular mechanisms of zinc uptake and translocation in rice. Plant Soil 36, 189-201. doi: 10.1007/s11104-012-1240-5

Bes, C. M., Pardo, T., Bernal, M. P., and Clemente, R. (2014). Assessment of the environmental risks associated with two mine tailing soils from the La Union-Cartagena (Spain) mining district. J. Geochem. Explor. 147, 98-106. doi: 10.1016/j.gexplo.2014.05.020

Bilski, J. J., Alva, A. K., and Sajwan, K. S. (1995). "Fly ash, " in Soil Amendments and Environmental Quality, ed J. E. Rechcigl (Boca Raton, FL: Lewis Publishers), 237-363.

Björkman, O., and Demmig, B. (1987). Photon yield of $\mathrm{O}_{2}$ evolution and chlorophyll fluorescence at $77 \mathrm{k}$ among vascular plants of diverse origins. Planta 170, 489-504. doi: 10.1007/BF00402983

\section{ACKNOWLEDGMENTS}

This work was supported by the Ministry of Education, Science and Technological Development of Serbia, Grant No. 173018. Two reviewers gave valuable comments for the improvement of this paper and we are greatly acknowledged.

Bovet, L., Eggmann, T., Meylan-Bettex, M., Polier, J., Kammer, P., et al. (2003). Transcript levels of AtMRPs after cadmium treatment: induction of AtMRP3. Plant Cell Environ. 26, 371-381. doi: 10.1046/j.1365-3040.2003.00968.x

Burken, J. G. (2003). "Uptake and metabolism of organic compounds: green liver model," in Phytoremediation, Transformation and Control of Contaminants, eds S. C. McCutcheon and J. L. Schnoor (Hoboken, NJ: John Wiley and Sons, Inc, Publications), 59-84.

Carlson, C. L., and Adriano, D. C. (1993). Environmental impacts of coal combustion residues. J. Environ. Qual. 22, 227-247. doi: 10.2134/jeq1993.00472425002200020002x

Castro, P. H., Lilay, G. H., and Assunção, A. G. L. (2018). "Regulation of micronutrient homeostasis and deficiency response in plants," in Plant Micronutrient Use Efficiency. Molecular and Genomics Perspectives in Crop Plants, eds M. A. Hossain, T. Kamiya, D. J. Burritt, L.-S. Phan Tran, and T. Fujiwara (London: Academic Press; Elsevier Inc.), 1-15.

Cervilla, L. M., Blasco, B., Rios, J. J., Rosales, M. A., Sanchez-Rodriguez, E., RubioWilhemi, M. M. et al. (2012). Parameters symptomatic for boron toxicity in leaves of tomato plants. J. Bot. 2012:726206. doi: 10.1155/2012/726206

Cheung, K. C., Wong, J. P. K., Zhang, Z. Q., Wong, J. W. C., and Wong, M. H. (2000). Revegetation of lagoon ash using the legume species Acacia auriculiformis and Leucaena leucocephala. Environ. Pollut. 109, 75-82. doi: 10.1016/S0269-7491(99)00235-3

Chu, M. (2008). natural revegetation of coal fly ash in a highly saline disposal lagoon in Hong Kong. Appl. Veg. Sci. 11, 297-306. doi: 10.3170/2008-7-18427

Clemens, S. (2006). Toxic metal accumulation, response to exposure and mechanisms of tolerance in plants. Biochimie 88, 1707-1719. doi: 10.1016/j.biochi.2006.07.003

Colpaert, J. V., Wevers, J. H., Krznaric, E., and Adriaensen, K. (2011). How metaltolerant ecotypes of ectomycorrhizal fungi protect plants from heavy metal pollution. Ann. For. Sci. 68, 17-24. doi: 10.1007/s13595-010-0003-9

Conesa, H., Faz, A., and Arnaldos, R. (2006). Heavy metal accumulation and tolerance in plants from mine tailings of the semiarid CartagenaLa Union mining district (SE Spain). Sci.Tot. Environ. 366, 1-11. doi: 10.1016/j.scitotenv.2005.12.008

Conte, S. S., and Walker, E. L. (2011). Transporters contributing to iron trafficking in plants. Mol. Plant 4, 464-476. doi: $10.1093 / \mathrm{mp} / \mathrm{ssr} 015$

Cooke, S. J., and Suski, C. D. (2010). Ecological restoration and physiology: an overdue integration. BioScience 58, 957-968. doi: 10.1641/B581009

Dimpka, C. O., Merten, D., Svatos, A., Büchel, G., and Kothe, E. (2009). Sideropohores mediates reduced and increased uptake of cadmium by Streptomyces tendae F4 and sunflower (Helianthus annus), respectively. J. Appl.Microbiol. 107, 1687-1696. doi: 10.1111/j.1365-2672.2009.04355.x

Djordjević-Miloradović, J. (1998). Population Dynamics of Plants in the Primary Succession of the Vegetation on the Waste Ash Deposits of the Thermoelectric Power Station Kostolac. Dissertation/Doctoral thesis, Faculty of Biology, University of Belgrade, Belgrade (in Serbian).

Djurdjević, L., Mitrović, M., Pavlović, P., Gajić, G., and Kostić, O. (2006). Phenolic acids as bioindicators of fly ash deposit revegetation. Arch. Environ. Contam. Toxicol. 50, 488-495. doi: 10.1007/s00244-005-0071-2

Dorner, J. (2002). An Introduction to Using Native Plants in Restoration Projects. Plant Conservation Alliance, Bureau of Land Management, US Department of Interior, US Environmental Protection Agency, 65.

Duponnois, R., Kisa, M., Assigbetse, K., Prin, Y., Thioulouse, J., Issartel, M., et al. (2006). Fluorescent pseudomonas occurring in Macrotermes subhyalinus mound structure decrease $\mathrm{Cd}$ toxicity and improve its accumulation in sorghum plants. Sci. Tot. Environ. 370, 391-400. doi: $10.1016 /$ j.scitotenv.2006.07.008 
Duy, D., Wanner, G., Meda, A., Von Wirén, N., and Soll, J., Et al. (2007). PIC1, an ancient permease in Arabidopsis chloroplasts, mediates iron transport. Plant Cell 19, 986-1006. doi: 10.1105/tpc.106.047407

Dwivedi, S., Srivastava, S., Mishra, S., Dixit, B., Kumar, A., and Tripathi, K. R. D. (2008). Screening of native plants and algae growing on fly-ash affected areas near National Thermal Power Corporation, Tanda, Uttar Pradesh, India for accumulation of toxic heavy metals. J. Hazard. Mater. 158, 359-365. doi: 10.1016/j.jhazmat.2008.01.081

Dwivedi, S., Tripathi, R. D., Srivastava, S., Mishra, S., Shukla, M. K., Tiwari, K. K., et al. (2007). Growth perfomance and biochemical responses of three rice (Oryza sativa L.) cultivars grown in fly-ash amended soil. Chemosphere 67,140-151. doi: 10.1016/j.chemosphere.2006.09.012

DŽeletović, Ž., and Filipović, R. (1995). Grain characteristics of crops grown on power plant ash and bottom slag deposit. Resour. Conserv. Recy. 13, 105-113. doi: 10.1016/0921-3449(94)00040-C

DŽeletović, Ž., Filipović, R. M., Stojanović, D., and Lazarević, M. M. (2009). Impact of lignite washery sludge on mine soil quality and poplar trees growth. Land Degrad. Dev. 20, 145-155. doi: 10.1002/ldr.888

Europian Commision (2009). Reference Document on Best-Available Techniques for Management of Tailings and Waste-Rock in Mining Activities. Available online at: http://eippcb.jrc.ec.europa.eu

Fernandez, S., Poschenrieder, C., Marceno, C., Gallego, J. R., Jimenez-Gamez, D., Bueno, A., et al. (2017). Phytoremediation capability of native plant species living on $\mathrm{Pb}-\mathrm{Zn}$ and $\mathrm{Hg}$-As mining wastes in the Cantabrian range, north Spain. J. Geochem. Explor. 174, 10-20. doi: 10.1016/j.gexplo.2016.05.015

Fettweis, U., Bens, O., and Huttl, R. F. (2005). Accumulation and properties of soil organic carbon at reclaimed mine sites in the Lusatian lignite mining district afforested with Pinus sp. Geoderma 129, 81-89. doi: 10.1016/j.geoderma.2004.12.034

Foyer, C., and Noctor, G. (2005). Redox homeostasis and antioxidant signaling: a metabolic interface between stress perception and physiological responses. Plant Cell 17, 1866-1875. doi: 10.1105/tpc.105.033589

Foyer, C., and Shigeoka, S. (2011). Understanding oxidative stress and antioxidant functions to enhance photosynthesis. Plant Physiol. 155, 93-100. doi: $10.1104 /$ pp.110.166181

Gajić, G., Djurdjević, L., Kostić, O., Jarić, S., Mitrović, M., Stevanović, B., et al. (2016). Assessment of the phytoremediation potential and an adaptive response of Festuca rubra L. Sown on fly ash deposits: native grass has a pivotal role in ecorestoration management. Ecol. Eng. 93, 250-261. doi: 10.1016/j.ecoleng.2016.05.021

Gajić, G., Mitrović, M., and Pavlović, P. (in press). "Ecorestoration of fly ash deposits by native plant species at thermal power stations (Serbia)" in Phytomanagement of Polluted Sites, eds V. C. Pandey and K. Bauddh (Amsterdam: Elsevier).

Gajić, G., Mitrović, M., Pavlović, P., Stevanović, B., Djurdjević, L., and Kostić, O. (2009). An assessment of the tolerance of Ligustrum ovalifolium Hassk.to traffic-generated $\mathrm{Pb}$ using physiological and biochemical markers. Ecotoxicol. Envirion. Saf. 72, 1090-1101. doi: 10.1016/j.ecoenv.2009.01.010

Gajić, G., and Pavlović, P. (2018). The role of vascular plants in the phytoremediation of fly ash deposits", in Phytoremediation: Methods, Management and Assessment, ed V. Matichenkov (New York, NY: Nova Science Publishers, Inc.), 151-236.

Gajić, G., Pavlović, P., Kostić, O., Jarić, S., Djurdjević, L., Pavlović, D., et al. (2013). Ecophysiological and biochemical traits of three herbaceous plants growing of the disposed coal combustion fly ash of different weathering stage. Arch. Biol. Sci. 65, 1651-1667. doi: 10.2298/ABS1304651G

Gajić, G., Stamenković, M., and Pavlović, P. (2018). "Plant photosynthetic response to metal(loid) stress," in Environment and Photosynthesis. A Future Prospect, eds V. P. Singh, S. Singh, R. Singh, S. M. Prasad (New Delhi: Studium Press (India), Pvt.Ltd), 145-209.

Gao, Y., Zhang, Y., Liu, J., and Kong, H. (2013). Metabolism and subcellular distribution of anthracene in tall fescue (Festuca arundinacea Schreb.). Plant Soil 365, 171-182. doi: 10.1007/s11104-012-1386-1

Gao, Y., and Zhu, L. (2004). Plant uptake, accumulation and translocation of phenanthrene and pyrene in soils. Chemosphere 55, 1169-1178. doi: $10.1016 /$ j.chemosphere.2004.01.037

Gomez-Ros, J. M., Garcia, G., and Penas, J. M. (2013). Assessment of restoration success of former metal mining areas after 30 years in a highly polluted
Mediterranean mining area: Cartagena-La Union. Ecol. Eng. 57, 393-402. doi: 10.1016/j.ecoleng.2013.04.044

Gonzalez, R. C., and Gonzalez-Chavez, M. C. A. (2006). Metal accumulation in wild plants surrounding mining wastes. Environ. Pollut. 144, 84-92. doi: 10.1016/j.envpol.2006.01.006

Grime, J. P. (1979). Plant Strategies and Vegetation Proceses. Chichester: John Wiley and Sons.

Gupta, A. K., and Sinha, S. (2008). Decontamination and/or revegetation of fly ash dykes through naturally growing plants. J. Hazard Mater. 153, 1078-1087. doi: 10.1016/j.jhazmat.2007.09.062

Hajibold, R., and Amirazad, F. (2010). Growth, photosynthesis and antioxidant defence system in Zn-deficient red cabbageplants. Plant Soil Environ. 56, 209-217. doi: 10.17221/207/2009-PSE

Hall, J. L., and Williams, L. E. (2003). Transition metal transporters in plants. J. Exp. Bot. 54, 2601-2613. doi: 10.1093/jxb/erg303

Halliwell, B. (2006). Reactive species and antioxidants. Redox biology is a fundamental theme of aerobic life. Plant Physiol. 141, 312-322. doi: $10.1104 /$ pp.106.077073

Harms, H., Dehen, W., and Moench, W. (1977). Benzo(a)pyrene metabolites formed by plant cells. Z. Naturforsch. 32c, 321-326. doi: 10.1515/znc-1977-5-602

Haydon, M. J., Kawachi, M., Wirtz, M., Hillmer, S., Hell, R., et al. (2012). Vacuolar nicotianamine has critical and distinct roles under iron defciency and for zinc sequestration in Arabidopsis. Plant Cell 24, 724-737. doi: 10.1105/tpc.111.095042

Haynes, R. J. (2009). Reclamation and revegetation of fly ash disposal sites - Challenges and research needs. J. Environ. Manage. 90, 43-53. doi: 10.1016/j.jenvman.2008.07.003

Heidrich, C. (2005). Summary of Tecnical Options for Coal Combustion Products Utilization in Australia. Wollongong, NSW: Ash Development Association of Australia.

Heidrich, C., Feueborn, H. J., and Weir, A. (2013). "Coal combustion products: a global perspective," Proceedings World of Coal Ash (WOCA) Conference, Lexington, KY, 22-25.

Hirshi, K. D., Korenkov, V. D., Wilganowski, N. L., and Wagner, G. J. (2000). Expression of Arabidopsis CAX2 in Tobacco. Altered metal accumulation and increased manganese tolerance. Plant Physiol. 124, 125-134. doi: $10.1104 / \mathrm{pp} .124 .1 .125$

Hodgson, D. R., and Townsend, W. N. (1973). “The amelioration and revegetation of pulverized fuel ash," in Ecology and Reclamation of Devastated Land, eds R.J. Hutnik and G. Davis (London: Gordon and Breach), 247-271.

Huang, X. D., El-Alawi, Y., Penrose, D. M., Glick, B. R., and Greenberg, B. M. (2004). A multi-process phytoremediation system for removal of polycyclic aromatic hydrocarbons from contaminated soils. Environ. Pollut. 130, 465-476. doi: 10.1016/j.envpol.2003.09.031

Inoue, H., Kobayashi, T., Nozoye, T., Takahashi, M., Kakei, Y., et al. (2009). Rice OsYSL15 is an iron-regulated Iron(III)-deoxymugineic acid transporter expressed in the roots and is essential for iron uptake in early growth of the seedlings. J. Biol. Chem. 284, 3470-3479. doi: 10.1074/jbc.M8060 42200

Ishimaru, Y., Kakei, Y., Shimo, H., Bashir, K., Sato, Y., Uozumi, N., et al. (2011). A rice phenolic efflux transporter is essential for solubilizing precipitated apoplasmic iron in the plant stele. J. Biol. Chem. 286, 24649-24655. doi: $10.1074 /$ jbc.M111.221168

Izquierdo, M., and Querol, X. (2012). Leaching behavior of elements from coal combustion fly ash: an overview. Int. J. Coal. Geol. 94, 54-66. doi: 10.1016/j.coal.2011.10.006

Jabeen, R., Ahmad, A., and Iqbal, M. (2009). Phytoremediation of heavy metals: physiological and molecular mechanisms. Bot. Rev. 75, 339-364. doi: 10.1007/s12229-009-9036-x

Jala, S., and Goyal, D. (2006). Fly ash as a soil ameliorant for iproving crop production - a review. Bioresour. Technol. 97, 1136-1147. doi: 10.1016/j.biortech.2004.09.004

Jambhulkar, H., and Juwarkar, A. A. (2009). Assessment of bioacumulation of heavy metals by different plant species grown on fly ash dump. Ecotoxicol. Envirion. Saf. 72, 1122-1128. doi: 10.1016/j.ecoenv.2008.11.002

Jimenez, M. N., Bacchetta, G., Casti, M., Navarro, F. B., Lallena, A. M., and Fernandez-Ondono, E. (2011). Potential use in phytoremediation of three plant 
species growing on contaminated mine-tailings soils in Sardinia. Ecol. Eng. 37, 392-398. doi: 10.1016/j.ecoleng.2010.11.030

Johansson, L., Xydas, C., Messios, N., Stoltz, E., and Greger, M. (2005). Growth and $\mathrm{Cu}$ accumulation by plants grown on $\mathrm{Cu}$ containing mine tailings in Cyprus. Appl. Geochem. 20, 101-107. doi: 10.1016/j.apgeochem.2004.07.003

Johnson, D. L., Anderson, D. R., and McGrath, S. P. (2005). Soil Microbial response during the phytoremediation of PAH contaminated soil. Soil Biol. Biochem. 37, 2334-2336. doi: 10.1016/j.soilbio.2005.04.001

Johnson, N. C. (1998). Responses of Salsola kali and Panicum virgatum to mycorhizzal fungi, phosphorus and soil organic matter: implications for reclamation. J. Appl. Ecol. 35, 86-94. doi: 10.1046/j.1365-2664.1998.00277.x

Jusaitis, M., and Pillman, A. (1997). Revegetation of waste fly ash lagoons. I. Plant selection and surfaceaamelioration. Waste. Manage. Res. 15, 307-321. doi: 10.1177/0734242X9701500308

Kabata-Pendias, A. (2011). Trace Elements in Soils and Plants, 4th Edn. Boca Raton, FL; London; New York, NY; Washington, DC: CRC Press LLC.

Kala, S. (2014). Rhizoremediation: a promising rhizosphere technology. J. Environ. Sci. Toxicol. Food Technol. 8, 23-27. doi: 10.5772/56905

Kasowska, D., Gediga, K., and Spiak, Z. (2018). Heavy metal and nutrient uptake in plants colonizing post-flotation copper tailings. Environ. Sci. Pollut. Res. 25, 824-835. doi: 10.1007/s11356-017-0451-y

Kidd, P., Barcelo, J., Bernal, M. P., Navari, I. F., Poschenrieder, C., Shilev, S., et al. (2009). Trace element behaviour at the root-soil interface: implications in phytoremediation. Environ. Exper. Bot. 67, 243-259. doi: 10.1016/j.envexpbot.2009.06.013

Kim, S. A., Punshon, T., Lanzirotti, A., Li, L., Alonso, J. M., et al. (2006). Localization of iron in Arabidopsis seed requires the vacuolar membrane transporter VIT1. Science 314, 1295-1298. doi: 10.1126/science.1132563

Kim, Y. Y., Choi, H., Segami, S., Cho, H. T., Martinoa, E., et al. (2009). AtHMA1 contribites to the detoxification of excess $\mathrm{Zn}$ (II) in Arabidopsis. Plant J. 58, 737-753. doi: 10.1111/j.1365-313X.2009.03818.x

Kobayashi, T., and Nishizawa, N. K. (2012). Iron uptake, translocation and regulation in higher plants. Annu. Rev. Plant Biol. 63, 131-152. doi: 10.1146/annurev-arplant-042811-105522

Kolb, M., and Harms, H. (2000). Metabolism of fluoranthene in different plant cell cultures and intact plants. Environ. Toxicol. Chem. 19, 1304-1310. doi: 10.1002/etc.5620190512

Kostić, O., Jarić, S., Gajić, G., Pavlovć, D., Pavlović, M., Mitrović, M., et al. (2018). Pedological properties and ecological implications of substrates derived 3 and 11 years after the revegetation of lignite fly ash disposal sites in Serbia. Catena 163, 78-88. doi: 10.1016/j.catena.2017.12.010

Kostić, O., Mitrović, M., KneŽević, M., Jarić.S., Gajić, G., Djurdjević, L., et al. (2012). The potential of four woody species for the revegetation of fly ash deposits from the 'Nikola Tesla -A' thermoelectric plant (Obenovac, Serbia). Arch. Biol. Sci. 64, 145-158. doi: 10.2298/ABS1201145K

Kuffner, M., Puschenreiter, M., Wieshammer, G., Gorfer, M., and Sessitsch, A. (2008). Rhizosphere bacteria affect growth and metal uptake of heavy metal accumulating willows. Plant Soil 304, 35-44. doi: 10.1007/s11104-007-9517-9

Kuiper, E. L., Lagendijk, G. V., and Lugtenberg, B. (2004). Rhizomediation: a beneficial plant microbe interaction. Mol. Plant Microbe Interact. 17, 6-15. doi: 10.1094/MPMI.2004.17.1.6

Kumar, A., Ahirwal, J., Maiti, S. K., and Das, R. (2015). An assessment of metal in fly ash and their translocation and bioaccumulation in perrenial grasses growing at the reclaimed opencast mines. Int. J. Env. Res. 9,1089-1096. doi: 10.22059/ijer.2015.996

Kumar, A., Prasad, M. N. V., Maiti, S. K., and Favas, P. J. S. (2018). "Mycoremediation for mine site rehabilitation", in Bio-Geotechnologies for Mine Site Rehabilitation, eds M. N. V. Prasad, P. J. C. Favas, and S. K. Maiti (Amsterdam: Elsevier), 233-253.

Kumari, A., Lal, B., and Rai, U. N. (2016). Assessment of native plant species for phytoremediation of heavy metals growing in the vicinity of NTPC sites, Kahagon, India. Int. J. Phytoremediat. 18, 592-597. doi: 10.1080/15226514.2015.1086301

Kumari, A., Pandey, V. C., and Rai, U. N. (2013). Feasibility of fern Thelypteris dentata for revegetation of coal fly ash landfills. J. Geochem. Explor. 128,147-152. doi: 10.1016/j.gexplo.2013.02.005

Lal, R., Negassa, W., and Lorenz, K. (2015). Carbon sequestration in soil. Curr. Opin. Environ. Sustain. 15, 79-86. doi: 10.1016/j.cosust.2015.09.002
Lanquar, V., Ramos, M. S., Lelievre, F., Barbier-Brygoo, H., Krieger-Liszkay, A., et al. (2010). Export of vacuolar manganese by AtNRAMP3 and AtNRAMP4 is required for optimal photosynthesis and growth under manganese deficiency. Plant Physiol. 152, 1986-1999. doi: 10.1104/pp.109.150946

Law, B. E., Falge, E., Gu, L., Baldocchi, D. D., Bakwin, P., Berbiger, P. et al. (2002). Environmental controls over carbon dioxide and water vapor exchange of terrestrial vegetation. Agric. For. Meterol. 113, 97-120. doi: 10.1016/S0168-1923(02)00104-1

Li, L., He, Z., Pandey, G. K., Tsuchia, T., and Luan, S. (2002). Functional cloning and characterization of a plant efflux carrier for multidrug and heavy metal detoxification. J. Biol. Chem. 277, 5360-5368. doi: 10.1074/jbc.M108777200

Li, L., Tutone, A. F., Drummond, R. S. M., Gardner, R. C., and Luan, S. (2001). A novel family of magnesium transport genes in Arabidopsis. Plant Cell 13, 2761-2775. doi: 10.1105/tpc.13.12.2761

Li, M. S., Luo, Y. P., and Su, Z. Y. (2007). Heavy metal concentrations in soils and plant accumulation in a restored manganese mineland in Guangxi, South China. Environ. Pollut. 147, 168-175. doi: 10.1016/j.envpol.2006.08.006

Liu, Z., Ge, H., Li, C., Zhao, Z., Song, F., and Hu, S. (2015). Enhanced phytoextraction of heavy metals from contaminated soil by plant co-cropping associated with PGPR. Water Air Soil Pollut. 226:29. doi: 10.1007/s11270-015-2304-y

Lopareva-Pohu, A., Garçon, G., Lounès-Hadj Sahraoui, A., Pourrut, B., Debiane, D., Waterlot, C., et al. (2011). Influence of fly ash aided phytostabilisation of $\mathrm{Pb}, \mathrm{Cd}$ and $\mathrm{Zn}$ highly contaminated soils on Lolium perenne and Trifolium repens metal transfer and physiological stress. Environ. Pollut. 159, 1721-1729. doi: 10.1016/j.envpol.2011.02.030

López-Millán, A. F., Ellis, D. R., and Grusak, M. A. (2004). Identification and characterization of several new members of the ZIP family of metal ion transporters in Medicago truncatula. Plant Mol. Biol. 4, 583-596. doi: 10.1023/B:PLAN.0000038271.96019.aa

Lopez-Orenes, A., Bueso, M., Parraga-Aguado, I. M., Calderon, A., and Ferrer, M. A. (2018). Coordinated role of soluble and cell wall bouund phenols is a key feature of the metabolic adjustment in mining woody fleabane (Dittrichia viscosa L.) population under semi-arid conditions. Sci. Tot. Environ. 618, 1139-1151. doi: 10.1016/j.scitotenv.2017.09.195

Lopez-Orenes, A., Bueso, M. C., Conesa, H. M., Calderon, A., and Ferer, M. (2017). Seasonal changes in antioxidative/oxidative profile of mining and non-mining populations of Syrian beancaper as determined by soil conditions. Sci. Tot. Environ. 575, 437-447. doi: 10.1016/j.scitotenv.2016.10.030

Lottermoster, B. (2012). Mine Wastes: Characterisation, Treatment and Environmental Impacts. New York, NY: Springer.

Lu, Y., Li, X., He, M., and Zeng, F. (2013). Behavior of native species Arrhenatherum elatius (Poaceae) and Sonchus transcapicus (Asteraceae) exposed to a heavy metal-polluted field: plant metal concentration, phytotoxicity, and detoxification responses. Int. J. Phytoremediat. 15, 924-937. doi: 10.1080/15226514.2012.735288

Lu, Y. F., Lu, M., Peng, F., Wan, Y., and Liao, M. H. (2014). Remediation of polychlorinated biphenyl-contaminated soil by using a combination of ryegrass, arbiscular mycorrhizal fungi and earthworms. Chemosphere 106,44-50. doi: 10.1016/j.chemosphere.2013.12.089

Ma, J. F., Yamaji, N., Mitani, N., Xu, X. Y., Su, Y. H., McGrath, S. P., et al. (2008). Transporters of arsenite in rice and their role in arsenic accumulation in rice grain. Proc. Natl. Acad. Sci. U.S.A. 105, 9931-9935. doi: $10.1073 /$ pnas.0802361105

Ma, Y., Prasad, M. N. V., Rajkumar, M., and Freitas, H. (2011). Plant growth promoting rhizobacteria and endophytes accelerate phytoremediation of metalliferous soils. Biotechnol. Adv. 29, 248-258. doi: 10.1016/j.biotechadv.2010.12.001

Macur, R. E., Wheeler, J. T., McDermott, T. R., and Inskeep, W. P. (2001). Microbial populations associated with the reduction and enhanced mobilization of arsenic in mine tailings. Environ. Sci. Technol. 35, 3676-3682. doi: 10.1021/es0105461

Madejon, P., Murillo, J. M., Maranon, T., Cabrera, F., and Lopez, R. (2002). Bioaccumulation of $\mathrm{As}, \mathrm{Cd}, \mathrm{Cu}, \mathrm{Fe}$, and $\mathrm{Pb}$ in wild grasses affected by the Aznalcollar mine spill. Sci. Tot. Environ. 290, 105-120. doi: 10.1016/S0048-9697(01)01070-1

Maiti, S. K. (2013). Ecorestoration of the Coalmine Degraded Lands. New Delhi: Springer. doi: 10.1007/978-81-322-0851-8 
Maiti, S. K., and Jaiswal, S. (2008). Bioaccumulation and translocation of metals in the natural vegetation growing on the fly ash dumps: a field study from Santal thermal power plant, West Bengal, India. Environ. Monit. Assess. 136, 355-370 doi: 10.1007/s10661-007-9691-5

Marschner, H. (1995). Mineral Nutrition of Higher Plants. London: Academic Press.

McCutcheon, S. C., and Schnoor, J. L. (2003). Phytoremediation: Transformation and Control of Contaminants. Hoboken, NJ: John Wiley and Sons, Inc. doi: 10.1002/047127304X

Memon, A. R., and Schröder, P. (2006). Implications of metal accumulation mechanisms to phytoremediation. Environ. Sci. Pollut. Res. 16, 162-175. doi: 10.1007/s11356-008-0079-z

Mertens, J., Van Nevel, L., De Schrijver, A., Piesschaert, F., Osterbean, A., Tack, F. M. G., et al. (2007). Tree species effect on the redistribution of soil metal. Environ. Pollut. 149, 173-181. doi: 10.1016/j.envpol.2007. 01.002

Migocka, M., and Malas, K. (2018). "Plant responses to copper: molecular and tegulatory mechanisms of copper uptake, distribution and accumulation in plants," in Plant Micronutrient Use Efficiency. Molecular and Genomics Perspectives in Crop Plants, eds M. A. Hossain, T. Kamiya, D. J. Burritt, L.-S. Phan Tran, and T. Fujiwara (London: Academic Press; Elsevier, Inc.), 71-86.

Mills, A. L. (1985). "Acid mine waste drainage: microbial impact on the recovery of soil and water ecosystems," in Soil Reclamation Processes: Microbiological Analyses and Applications, eds R. L. Tate and D. A. Klein (New York, NY: Marcel Dekker, Inc.), 35-82.

Mitrović, M., Pavlović, P., Lakušić, D., Stevanović, B., Djurdjevic, L., Kostić, O., et al. (2008). The potencial of Festuca rubra and Calamagrostis epigejos for the revegetation on fly ash deposits. Sci. Tot. Environ. 72, 1090-1101. doi: 10.1016/j.scitotenv.2008.09.001

Mittler, R. (2002). Oxidative stress, antioxidants and stress tolerance. Trends Plant Sci. 7, 405-410. doi: 10.1016/S1360-1385(02)02312-9

Miwa, K., Takano, J., Omori, H., Seki, M., and Shinozaki, K. (2007). Plants tolerant of high boron levels. Science 318:1417. doi: 10.1126/science.1146634

Moreira, A., Moraes, L. A. C., and dos Reis, A. R. (2018). "The molecular genetics of zinc uptake and utilization efficiency in crop plants," in Plant Micronutrient Use Efficiency. Molecular and Genomics Perspectives in Crop Plants, eds M. A. Hossain, T. Kamiya, D. J. Burritt, L.-S. Phan Tran, and T. Fujiwara (London: Academic Press; Elsevier, Inc.), 87-108.

Morgenthal, T. L., Cilliers, S. S., Kellner, K., van Hamburg, H., and Michael, M. D.,(2001). The vegetation of fly ash disposal sites at hendrina power station II: floristic composition. S. Afr. J. Bot. 67, 520-532. doi: 10.1016/S0254-6299(15)31184-4

Morrissey, J., Baxter, I. R., Lee, J., Li, L., Lahner, B., et al. (2009). The ferroportin metal efflux proteins function in iron and cobalt homeostasis in Arabidopsis. Plant Cell 21, 3326-3333. doi: 10.1105/tpc.109.069401

Moynahan, O. S., Zabinski, C. A., and Gannon, J. E. (2002). Microbial community structure and carbon-utilization diversity in a mine tailings revegetation study. Restor. Ecol. 10, 77-87. doi: 10.1046/j.1526-100X.2002. 10108.x

Mukherjee, I., Campbell, N. H., Ash, J. S., and Connolly, E. L. (2006). Expression profiling of the Arabidopsis ferric chelate reductase (FRO) gene family reveals differential regulation by iron and copper. Planta 223, 1178-1190. doi: 10.1007/s00425-005-0165-0

Mukhopadhyay, S., and Maiti, S. K. (2014). Soil $\mathrm{CO}_{2}$ flux in grassland, afforested land and reclaimed coalmine overburden dumps: a case study. Land Degrad. Dev. 25, 216-227. doi: 10.1002/ldr.1161

Mulhern, D. W., Robel, R. J., Furness, J. C., and Hensley, D. L. (1989). Vegetation of waste disposal areas at a coal-fired power plant in Kansas. J. Environ. Qual. 18, 285-292. doi: 10.2134/jeq1989.00472425001800030007x

Mummey, D. L., Stahl, P. D., and Buyer, J. (2002). Soil microbiological properties 20 years after surface mine reclamation: spatial analysis of reclaimed and undisturbed sites. Soil Biol Biochem. 34, 1717-1725. doi: 10.1016/S0038-0717(02)00158-X

Nadgorska-Socha, A., Ptasinski, B., and Kita, A. (2013). Heavy metal bioaccumulation and antioxidative responses in Cardamine arenosa and Plantago lanceolata leaves from mtalliferous and nin-metalliferous sites: a feld study. Ecotoxicology 22, 1422-1434. doi: 10.1007/s10646-013-1129-y

Nakanishi, H., Ogawa, I., Ishimaru, Y., Mori, S., and Nishizawa, N. K. (2006). Iron deficiency enhances cadmium uptake and translocation mediated by the $\mathrm{Fe}^{2+}$
Transporters OsIRT1 and OsIRT2 in Rice. Soil Sci. Plant Nutr. 52, 464-469. doi: $10.1111 / j .1747-0765.2006 .00055 . x$

Nikolić, M., and Pavlović, J. (2018). Plant responses to iron deficiency and toxicity and iron use efficiency in plants", in Plant Micronutrient Use Efficiency. Molecular and Genomics Perspectives in Crop Plants, eds M. A. Hossain, T. Kamiya, D. J. Burritt, L-S. Phan Tran, and T. Fujiwara (London: Academic Press, Elsevier, Inc.), 55-69.

Nikolić, N., Böcker, R., Kostić-,Kravljanac, L.j., and Nikolić, M. (2014). Assembly processes under severe abiotic filtering: adaptation mechanisms of weed vegetation to the gradient of soil constrains. PLoS ONE 9:e114290. doi: 10.1371/journal.pone. 0114290

Nikolić, N., Böcker, R., and Nikolić, M. (2016). Long-term passive restoration following fluvial deposition of sulphidic copper tailings: nature filters out the solutions. Environ. Sci. Pollut. Res. 23, 1362-1380. doi: 10.1007/s11356-018-3272-8

Noyd, R. K. F. L., Pfleiger, M. R., Norland, M. R., and Sadowsky, M. J. (1995). Native prairie grasses and microbial community response to reclamation of taconite ore tailing. Can. J. Bot. 73, 1645-1654. doi: 10.1139/b95-178

Nozoye, T., Nagasaka, S., Kobayashi, T., Takahashi, M., Sato, Y., et al. (2011). Phytosiderophore efflux transporters are crucial for iron acquisition in graminaceous plants. J. Biol. Chem. 286, 5446-5454. doi: 10.1074/jbc.M110.180026

Nwoko, C. O. (2010). Trends in phytoremediation of toxic elemental and organic pollutants. Afr. J. Biotechnol. 9, 6010-6016. doi: 10.5897/AJB09.061

Olson, K. R., Al-Kaisi, M. M., Lal, R., and Lowery, B. (2014). Experimental consideration, treatments and methods in determining soil organic carbon sequestration rates. Soil Sci. Soc. Am. J. 78, 348-360. doi: 10.2136/sssaj2013.09.0412

Pandey, V. C. (2012). Invasive species based efficient green technology for phytoremediation of fly ash deposits. J. Geochem. Explor. 123, 13-18. doi: 10.1016/j.gexplo.2012.05.008

Pandey, V. C. (2013). Suitability of Ricinus communis L. cultivation for phytoremediation of fly ash disposal sites. Ecol. Eng. 57, 336-341. doi: 10.1016/j.ecoleng.2013.04.054

Pandey, V. C. (2015). Assisted phytoremediation of fly ash dumps through naturally colonized plants. Ecol. Eng. 82, 1-5. doi: 10.1016/j.ecoleng.2015.04.002

Pandey, V. C., Bajpai, O., and Sinhg, N. (2016a). Plant regeneration potential in fly ash ecosystem. Urban For. Urban Greening 15, 40-44. doi: 10.1016/j.ufug.2015.11.007

Pandey, V. C., Pandey, D. N., and Singh, N. (2015a). Sustainable phytoremediation based on naturally colonizing and economically valuable plants. J. Clean Prod. 86, 37-39. doi: 10.1016/j.jclepro.2014.08.030

Pandey, V. C., Prakash, P., Bajpai, O., Kumar, A., and Sing, N. (2015b). Phytodiversity on fly ash deposits: evaluation of naturally colonized species for sustainable phytorestoration. Environ. Sci. Pollut. Res. 22, 2776-2787. doi: 10.1007/s11356-014-3517-0

Pandey, V. C., Sahu, N., Behera, S. K., and Singh, N. (2016b). Carbon sequestration in fly ash dumps: Comparative assessment of three plant asociation. Ecol. Eng. 95, 198-205. doi: 10.1016/j.ecoleng.2016.06.010

Pandey, V. C., Singh, J. S., Kumar, A., and Tewari, D. D. (2010). Accumulation of Heavy Metals by Chickpea Grown in Fly Ash Treated Soil: Effects on Antioxidants. CLEAN Soil Air Water 38, 1116-1123. doi: $10.1002 /$ clen.201000178

Pandey, V. C., Singh, K., Singh, R. P., and Singh, B. (2012). Naturally growing Saccharum munja L. On the fly ash lagoons: A potential ecological engineer for the revegetation and stabilization. Ecol. Eng. 40, 95-99. doi: 10.1016/j.ecoleng.2011.12.019

Pandey, V. C., and Singh, N. (2014). Fast green capping on coal fly ash basins through ecological engineering. Ecol. Eng. 73, 671-675. doi: 10.1016/j.ecoleng.2014.09.036

Pandey, V. C., Singh, N., Singh, R. P., and Singh, D. P. (2014). Rhizomediation potential of spontaneous grown Typha latifolia on fly ash basins: study from the field. Ecol. Eng. 71, 722-727. doi: 10.1016/j.ecoleng.2014.08.002

Pang, Y., Li, L., Ren, F., Lu, P., Wei, P., et al. (2010). Overexpression of the tonoplast aquaporin AtTIP5;1 conferred tolerance to boron toxicity in Arabidopsis. J. Genet. Genomics 37, 389-397. doi: 10.1016/S1673-8527(09) 60057-6 
Parraga-Aguado, I., Gonzales-Alcaraz, M.-N., Alvarez-Rogel, J., Jimenes-Carceles, F. J., and Conesa, H. M. (2013). The importance of edaphic niches and pioneer plant species succession for the phytomanagement of mine tailings. Environ. Pollut. 176, 134-143. doi: 10.1016/j.envpol.2013.01.023

Parraga-Aguado, I., Querejeta, J.-I., Gonzales-Alcaraz, M.-N., Jimenez-Carceles, F. J., and Conesa, H. M. (2014). Usefulness of pioneer vegetation for the phytomanagement of metal(lod)s enriched tailings: grasses vs. shrubs vs. trees. J. Environ. Manage. 133, 51-58. doi: 10.1016/j.jenvman.2013. 12.001

Pavlović, P., Mitrović, M., and Djurdjevic, L. (2004). An ecophysiological study of plants growing on the fly ash deposits from the "Nikola Tesla-A" thermal power station in Serbia. Environ. Manage. 33, 654-663. doi: 10.1007/s00267-004-2928-y

Pedas, P., Hebbern, C. A., Schjoerring, J. K., Holm, P. E., and Husted, S. (2005). Differential capacity for high-affinity manganese uptake contributes to differences between barley genotypyes in tolerance to low manganese availability. Plant Physiol. 139, 1411-1420. doi: 10.1104/pp.105.067561

Persans, M. W., Neiman, K., and Salt, D. E. (2001). Functional Activity and Role of Cation-Efflux Family Members in Ni hyperaccumulation in Thlaspi goesingense. Proc. Natl. Acad. Sci. U.S.A. 98, 9995-10000. doi: $10.1073 /$ pnas. 171039798

Petrisor, I. G., Dobrota, S., Komnitsas, K., Lazar, I., Kuperberg, J. M., and Serban, M. (2004). Artifical inoculation? Perspectives in tailings phytostabilization. Int. J. Phytoremediat. 6, 1-15. doi: 10.1080/16226510490439918

Petrová, Š., Rezek, J., Soudek, P., and Vaněk, T. (2017). Preliminary study of phytoremediation of brownfield soil contaminated by PAHs. Sci. Tot. Environ. 599-600, 572-580. doi: 10.1016/j.scitotenv.2017.04.163

Pilon-Smits, E., and LeDuc, D. L. (2009). Phytoremediation of selenium using transgenic plants. Curr. Opin. Biotechnol. 20, 207-212. doi: 10.1016/j.copbio.2009.02.001

Pistelli, L., D’Angiolillo, F., Morelli, E., Basso, B., Roselllini, I., Posarelli, M., et al. (2017). Response of spontaneous plant from an ex-mining site of Elba island (Tuscany, Italy) to metal(loid) contamination. Environ. Sci. Pollut. Res. 24; 7809-7820. doi: 10.1007/s11356-017-8488-5

Pourrut, B., Shahid, M., Dumat, C., Winterton, P., and Pinelli, E. (2011). Lead uptake, toxicity, and detoxification in plants. Rev. Environ.Contam. T. 213, 113-136. doi: 10.1007/978-1-4419-9860-6_4

Prasad, M. N. V. (2006). "Stabilization, remediation, and integrated management of metal-contaminated ecosystems by grasses (Poaceae)," in Trace Elements in the Environment (Biogeochemistry, Biotechnology, and Bioremediation), eds M. N. V. Prasad, K. S. Sajwan, and R. Naidu (Boca Raton, FL: CRC Taylor and Francis), 405-424.

Pratas, J., Favas, P. J. C., D'Souza, R., Varun, M., and Pau, M. S. (2013). Phytoremediation assessment of flora tolerant to heavy metals in the contaminated soils of an abandoned $\mathrm{Pb}$ mine in Central Portugal. Chemosphere 90, 2216-2225. doi: 10.1016/j.chemosphere.2012. 09.079

Puig, N., Andreas-Colas, A., Garcia-Molina, A., and Penarrubia, L. (2007). Copper and iron homeostasis in Arabidopsis: responses to metal deficiencies, interaction and biotechnology applications. Plant Cell Environ. 30, 271-290. doi: 10.1111/j.1365-3040.2007.01642.x

Randjelović, D., Cvetković, V., Mihailović, N., and Jovanović, S. (2014). Relationship between edaphic factors and vegetation development on copper mine wastes: a case study from Bor (Serbia, SE Europe). Environ. Manage. 53, 800-812. doi: 10.1007/s00267-014-0240-z

Randjelović, D., Gajić, G., Mutić, J., Pavlović, P., Mihailović, N., and Jovanović, S. (2016). Ecological potential of Epilobium dodonaei Vill. For restoration of metalliferous mine waste. Ecol. Eng. 95, 800-810. doi: 10.1016/j.ecoleng.2016.07.015

Raskin, I., Smith, R. D., and Salt, D. E. (1997). Phytoremediation of metals: using plants to remove pollutants from the environment. Curr. Opin. Biotechnol. 8, 22-26. doi: 10.1016/S0958-1669(97)80106-1

Reeves, R. D., and Baker, A. J. M. (2000). "Metal-Accumulating Plants," in Phytoremediation of Toxic Metals: Using Plants to Cleanup the Environment, eds I. Raskin and B. D. Ensley (New York, NY: John Wiley and Sons, Inc, Publications), 193-229.

Reid, R. (2014). Understanding the boron transport network in plants. Plant Soil. 385, 1-13. doi: 10.1007/s11104-0412-2149-y
Reid, R., and Fitzpatrick, K. (2009). Influence of leaf tolerance mechanisms and rain on boron toxicity in barley and wheat. Plant Physiol. 151, 413-420. doi: $10.1104 /$ pp.109.141069

Reijnders, L. (2005). Disposal, uses and treatments of combustion ashes: a review. Resour. Conserv. Recycl. 43, 313-336. doi: 10.1016/j.resconrec.2004.06.007

Richards, R. T., Chambers, J. C., and Ross, C. (1998). Use of native plants on federal lands: policy and practice. J. Range Manage. 51, 625-632. doi: 10.2307/4003603

Ruiz Olivares, A., Carillo-Gonzales, R., del Carmen, M.a., Gonzales-Chavez, A., and Hernandez, R. M. S. (2013). Potential of castor bean (Ricinus communis L.) for phytoremediation of mine tailings and oil production. J. Environ. Manage. 114, 316-323. doi: 10.1016/j.jenvman.2012.10.023

Safranova, V. I., Piluzza, G., Zinovkina, N. Y., Kimeklis, A. K., Belimov, A. A., and Bullita, S. (2012). Relationship between pasture legumes, rhizobacteria, nodule bacteria in heavy metal polluted mine waste of SW Sardinia. Symbiosis 58, 149-159. doi: 10.1007/s13199-012-0207-x

Salt, D. E., Smith, R. D., and Raskin,. I. (1998). Phytoremediation. Annu. Rev. Plant Physiol. 49, 643-668. doi: 10.1146/annurev.arplant.49.1.643

Sandermann, H. (1994). Higher Plant Metabolism of Xenobiotics: the "Green Liver" Concept. Pharmacogenetics 4, 225-241.

Santos, A. E., Cruz-Ortega, R., Meza-Figueroa, D., Romero, F. M., SanchezEscalante, J. J., Maier, R. M., et al. (2017). Plants from the abandoned Nacozari mine tailings: evaluation of their phytostabilization potential. Perr 5:e3280. doi: $10.7717 /$ peerj.3280

Santos, E. S., Abreu, M. M., and Magalhaes, M. C. F. (2016). Cistus ladanifer phytostabilizing soils contaminated with non-essential chemical elements. Ecol. Eng. 94, 107-116. doi: 10.1016/j.ecoleng.2016.05.072

Sasaki, A., Yamaji, N., Yokosho, K., and Ma, J. F. (2012). Nramp5 Is a major transporter responsible for manganese and cadmium uptake in rice. Plant Cell 24, 2155-2167. doi: 10.1105/tpc.112.096925

SER (2002). The SER Primer on Ecological Restoration. Society for Ecological Restoration and Policy Working Group.

Shaw, P. J. A. (1996). Role of seedbank substrates in the revegetation of fly ash and gypsum in the United Kingdom. Restoration Ecol. 4, 61-70. doi: 10.1111/j.1526-100X.1996.tb00108.x

Sheng, H. A. O., Yang, Y., and Yang, Z., et al. (2010). The dynamic response of soil respiration to land-use changes in subtropical China. Glob. Change Biol. 16, 1107-1121. doi: 10.1111/j.1365-2486.2009.01988.x

Shigaki, T., Pittman, J. K., and Hirschi, K. D. (2003). Manganese Specifity Determinants in the ArabidopsisMetal/ $\mathrm{H}^{+}$Antiporter CAX2. J. Biol. Chem. 279, 9091-9096. doi: 10.1074/jbc.M209952200

Sinclair, S. A., and Krämer, U. (2012). The zinc homeostasis netweork of land plants. Biochim. Biophys. Acta 1823, 1553-1567. doi: 10.1016/j.bbamcr.2012.05.016

Singh, A., Sharma, R. K., and Agrawal, S. B. (2008). Effects of fly ash incorporation on heavy metal accumulation, growth and yield responses of Beta vulgaris plants. Bioresour. Technol. 99, 7200-7207. doi: 10.1016/j.biortech.2007.12.064

Singh, S., Parihar, P., Singh, R., Singh, V. P., and Prasad, S. M. (2016). Heavy metal tolerance in plants: role of transcriptomics, proteomics, metabolomics, and ionomics. Front. Plant Sci. 6:1143. doi: 10.3389/fpls.2015.01143

Sinha, S., and Gupta, A. K. (2005). Translocation of metals from fly ash amended soil in the plant of Sesbania cannabina L. Ritz.: Effect on antioxidants. Chemosphere 61, 1204-1214. doi: 10.1016/j.chemosphere.2005.02.063

Song, W. Y., Choi, K. S., Kim, D. Y., Geisler, M., Park, J., et al. (2010). Arabidopsis PCR2 is a zinc exporter involved in both zinc extrusion and long-distance zinc transport. Plant Cell 22 , 2237-2252. doi: 10.1105/tpc.109.070185

Sunkar, R., Kaplan, B., Bouche, N., Arazi, T., Dolec, D., et al. (2000). Expression of a truncated tobacco NtCBP4 channel in transgenic plants and disruption of the homologous Arabidopsis CNGC1 gene confer $\mathrm{Pb}^{2+}$ tolerance. Plant J. 24, 533-542. doi: 10.1046/j.1365-313x.2000.00901.x

Takahashi, M., Terada, Y., Nakai, I., Nakanishi, H., Yoshimura, E., et al. (2003). Role of nicotianamine in the intracellular delivery of metals and plant reproductive development. Plant Cell 15, 1263-1280. doi: 10.1105/tpc.010256

Takano, J., Kobayashi, M., Noda, Y., and Fujiwara, T. (2007). Saccharomyces cerevisiae Borlp is a boron exporter and a key determinant of boron tolerance. FEMS Microbiol Immunol. 267, 230 - 235. doi: 10.1111/j.1574-6968.2006.00556.x

Tao, S., Ciu, Y. H., Xum, F. L., Li, B. G., Cao, J., Liu, W. X., et al. (2004). Polyclic Aromatic Hydrocarbons (PAHs) in Agricultural Soil and Vegetables 
from Tianjin. Sci. Tot. Environ. 320, 11-24. doi: 10.1016/S0048-9697(03) 00453-4

Teng, Y., Luo, Y., Sun, X., Tu, C., Xu, L., Liu, W., et al. (2010). Influence of arbiscular mycorrhiza and rhizobium on phytoremediation by alfafa of an agricultural soil contaminated with weathered PCBs: a field study. Int. J. Phytoremediat. 12, 516-533. doi: 10.1080/15226510903353120

Thomine, S., Lelievre, F., Debarbieux, E., Schroder, J. I., and BarbierBygoo, H. (2003). AtNRAMP3, a multispecific vacuolar metal transporter involved in plant responses to iron deficiency. Plant J. 34, 685-695. doi: 10.1046/j.1365-313X.2003.01760.x

Thomine, S., Wang, R., Ward, J. M., Crawford, N. M., and Schroeder, J. I. (2000). Cadmium and iron transport by members of a plant metal transporter family in Arabidopsis with homology to Nramp genes. Proc. Natl. Acad. Sci. U.S.A. 97, 4991-4996. doi: 10.1073/pnas.97.9.4991

Tokala, R. K., Strap, J. L., Jung, C. M., Crawford, D. L., Salove, H., Deobald, L. A., et al. (2002). Novel plant- microbe rhizosphere interaction involving S. lydicus WYEC108 and the pea plant (Pisum sativum). Appl. Environ. Microbiol. 68, 2161-71. doi: 10.1128/AEM.68.5.2161-2171.2002

Tong, Y. P., Kneer, R., and Zhu, Y. G. (2004). Vacuolar compartmentalization: a second-generation approach to engineering plants for phytoremediation. Trends Plant Sci. 9, 8-9. doi: 10.1016/j.tplants.2003.11.009

Tripathi, D. K., Singh, S., Gaur, S., Singh, S., Yadav, V., Liu, S., et al. (2018). Acquisition and homeostasis of iron in higher plants and their probable role in abiotic stress tolerance. Front. Environ. Sci. 5:86. doi: 10.3389/fenvs.2017.00086

Tripathi, R. D., Srivastava, S., Mishra, S., Singh, N., Tuli, R., et al. (2007). Arsenic hazards: strategies for tolerance and remediation by plants. Trends Biotechnol. 25, 158-165. doi: 10.1016/j.tibtech.2007.02.003

Turnau, K., Gawronski, S., Ryszka, P., and Zook, D. (2012). "Mycorrhizal-based phytostabilization of $\mathrm{Zn}-\mathrm{Pb}$ tailings: lessons from the Trzebionka mining works (Southern Poland)," in Bio-geo Interactions in metal - Contamnated Soils, eds E. Kothe and A. Varma (Berlin; Heidelberg: Springer-Verlag), 327-348.

US Environmental Protection Agency, USEPA (2007). Human and Ecological Risk Assessment of Coal Combustion Wastes. USEPA.

Utmazian, M. N. D. S., Wieshammer, G., Vega, R., and Wenzel, W. W. (2007). Hydroponic screening for metal resistance and accumulation of cadmium and zinc in twenty clones of willows and poplars. Environ. Pollut. 148, 155-165. doi: 10.1016/j.envpol.2006.10.045

Van Assche, F., and Clijsters, H. (1990). Effects of metals on enzyme activity in plants. Plant Cell Environ. 13, 195-206. doi: 10.1111/j.1365-3040.1990.tb01304.x

Van Rensburg, L., Morgenthal, T. L., Van Hamburg, H., and Michael, M. D. (2003). A comparative analysis of the vegetation and topsoil cover nutrient status between two similarly rehabilitated ash disposal sites. Environmentalist 23, 285-295. doi: 10.1023/B:ENVR.0000031359.70523.4a

Verbruggen, N., Hermans, C., and Schat, H. (2009). Mechanisms to cope with arsenic or cadmium excess in plants. Curr. Opin. Plant Biol. 12, 1-9. doi: 10.1016/j.pbi.2009.05.001

Weber, H., Chetelat, A., Reymond, P., and Farmer, E. E. (2004). Selective and powerful stress gene expression in Arabidopsis in response to malondialdehyde. Plant J. 37, 877-888. doi: 10.1111/j.1365-313X.2003.02013.x

Weber, J., Straczynska, S., Kocowicz, A., Gilewska, M., Bogacz, A., Gwizdz, M., et al. (2015). Properties of soil materials derived from fly ash 11 years after revegetation of post-mining excavation. Catena 133, 250-254. doi: 10.1016/j.catena.2015.05.016
Wilken, A., Bock, C., Bokern, M., and Harms, H. (1995). Metabolism of Different PCB Congeners by Plant Cell Cultures. Environ.Toxicol. Chem. 14, 2017-2022. doi: $10.1002 /$ etc.5620141203

Wong, C. K. E., and Cobbett, C. D. (2009). HMA Type ATPAses Are the Major Mechanism for Root to Shoot Translocation in Arabidopsis thaliana. New Phytol. 181, 71-78. doi: 10.1111/j.1469-8137.2008.02638.x

World Coal Association (2012). Coal Facts 2012.

Wu, S., Cheung, K., Luo, Y., and Wong, M. (2006). Effects of inoculation of plant growth-promoting rhizobacteria on metal uptake by Brassica juncea. Environ. Pollut. 140, 124-135. doi: 10.1016/j.envpol.2005.06.023

Wu, Z., Liang, F., Hong, B., Young, J. C., Sussman, M. R., et al. (2002). An Endoplasmatic reticulum-bound $\mathrm{Ca}^{2+} / \mathrm{Mn}^{2+}$ Pump, ECA1, supports plant growth and confers tolerance to $\mathrm{Mn}^{2+}$ stress. Plant Physiol. 130, 128-137. doi: 10.1104/pp.004440

Yang, X., Ying, F., He, Z., and Stoffella, P. J. (2005). Molecular mechanisms of heavy metal hyperaccumulation and phytoremediation. J. Trace. Elem. Med. Bio. 18, 339-353. doi: 10.1016/j.jtemb.2005.02.007

Yao, Z. T., Ji, X. S., Sarker, P. K., Tang, J. H., Ge, L. Q., Xia, M. S., et al. (2015). A comprehensive review on the applications of coal fly ash. Earth Sci. Rev. 141, 105-121. doi: 10.1016/j.earscirev.2014.11.016

Yoon, J., Cao, X., Zhou, Q., and and, L. Q., Ma (2006). Accumulation of Pb, Cu, and $\mathrm{Zn}$ in native plants growing on a contaminated Florida Site. Sci. Tot. Environ. 368, 456-464. doi: 10.1016/j.scitotenv.2006.01.016

Yruela, I. (2009). Copper in plants: acquisition, transport and interactions. Funct. Plant Biol. 36, 409-430. doi: 10.1071/FP08288

Zarei, M., Konig, S., Hempel, S., Nekouei, M. K., Savaghebi, G., and Buscot, F. (2008). Community structure of arbiscular mycorrhizal fungi associated to Veronica rechingeri at the Anguran zinc and lead mining region. Environ. Pollut. 156, 1277-1283. doi: 10.1016/j.envpol.2008.03.006

Zhang, R., Liu, G., Wu, N., Gu, M., Zeng, H., Zhu, Y., et al. (2011). Adaptation of plasma membrane $\mathrm{H}^{+}$ATPase and $\mathrm{H}^{+}$pump to $\mathrm{p}$ deficiency in rice roots. Plant Soil 349, 3-11. doi: 10.1007/s11104-011-0774-2

Zhang, Y., Yang, J., Wu, H., Shi, C., Zhang, C., Li, D., et al. (2014). Dynamic changes in soil and vegetation during varying ecological-recovery conditions of abandoned mines in Beijing. Ecol. Eng. 73, 676-683. doi: 10.1016/j.ecoleng.2014.09.113

Zhang, Y., Zhang, Y., Liu, M., Shi, X., and Zhao, Z. (2008). Dark septate endophyte (DSE) fungi isolated from metal polluted soils: their taxonomic position, tolerance, and accumulation of heavy metals in vitro. J. Microbiol. 46, 624-632. doi: $10.1007 /$ s12275-008-0163-6

Conflict of Interest Statement: The authors declare that the research was conducted in the absence of any commercial or financial relationships that could be construed as a potential conflict of interest.

The handling editor declared a shared affiliation, though no other collaboration, with the authors at the time of review.

Copyright (c) 2018 Gajić, Djurdjević, Kostić, Jarić, Mitrović and Pavlović. This is an open-access article distributed under the terms of the Creative Commons Attribution License (CC BY). The use, distribution or reproduction in other forums is permitted, provided the original author(s) and the copyright owner(s) are credited and that the original publication in this journal is cited, in accordance with accepted academic practice. No use, distribution or reproduction is permitted which does not comply with these terms. 